\title{
Modelling reach-scale variability in sediment remobilisation potential: an approach for within-reach prioritisation of river rehabilitation works
}

\author{
Jo Hoyle ${ }^{1^{*}}$, Andrew Brooks ${ }^{2}$, John Spencer ${ }^{2}$ \\ * Contact author: email j.hoyle@niwa.co.nz, ph: +64 3348 8987, fax: +64 33485548 \\ ${ }^{1}$ National Institute of Water and Atmospheric Research, 10 Kyle Street, Riccarton, Christchurch 8011, New \\ Zealand \\ ${ }^{2}$ Australian Rivers Institute, Griffith University, Nathan, Queensland, 4111, Australia
}

\begin{abstract}
In Australia many river ecosystems are adversely affected by significant increases in channel dimensions and upstream sediment yield occurring in the period since European settlement. To date, various tools have been developed to help identify key sources of sediment supply at the catchment scale. This is often at a resolution that is too coarse to be translated directly to on-ground rehabilitation works, as most riverworks programs are designed and implemented at the reach or within-reach scale. This investigation focuses on a $10 \mathrm{~km}$ reach of the upper Hunter River, NSW, Australia, examining within-reach spatial variability in sediment entrainment potential. We present the results of a highresolution reach-scale modelling approach, examining excess shear velocity distribution using the widely available model HEC-RAS, and incorporating a detailed, LiDARderived, representation of the in-channel vegetation into a spatially distributed Manning's roughness layer. At the geomorphic unit scale, the results highlight that the elevated 'bench' units, which represent significant stores of sand and silt, are much more vulnerable to remobilisation than the lower elevation gravel bar units. At the sub-reach scale $(500-2000 \mathrm{~m})$ shear velocities are greatest in the most confined sections. While instream geomorphic heterogeneity has been significantly reduced in these locations, ongoing erosion is limited by bedrock and buried terrace material in the bed and banks. These results stress the need for highly targeted rehabilitation strategies that account for within-reach variability in entrainment potential as well as on-the-ground knowledge of sediment supply and geological controls.
\end{abstract}

\section{Key words}

river restoration, river rehabilitation, management prioritisation, within-reach variability, revegetation success, erosion potential, LiDAR 


\section{Introduction}

Along many south-east Australian rivers, channel morphology and bedload transport relationships have been comprehensively modified as a result of European settlement disturbance. Typically, many alluvial rivers have undergone a substantial increase in channel capacity through incision, expansion and channel straightening (Brooks and Brierley, 1997; Fryirs and Brierley, 2001; Nanson and Erskine, 1988; Page and Carden, 1998), largely in response to channelisation, stock disturbance and removal of riparian vegetation and instream wood. It has been estimated that in some catchments sediment supply from channel erosion and network extension has increased by two orders of magnitude above the pre European rate (Wasson et al., 1996). In addition to the economic costs of treating channel instability (White et al., 1999), and the downstream impacts of accelerated sediment supply (Douglas et al., 2003; McKergow et al., 2005), there is increasing concern for the sustainability and biodiversity of aquatic and riparian ecosystems impacted by sedimentation (Bond and Lake, 2003; Boulton, 2007). Alterations to channel morphology and the 'natural' patterns and rates of change in rivers can have significant impact on the ecological integrity of a river, in some cases diminishing its ability to support ecological systems (Naiman et al., 2002).

Over the last few decades there has been a fundamental attitudinal shift towards a more ecosystem focused approach to land and river management (Hillman \& Brierley, 2005) and increased efforts to recover degraded landscapes and ecosystems (Bernhardt et al., 2005, Brooks and Lake, 2007). Riparian revegetation is by far the most ubiquitous rehabilitation technique used today in Australia and internationally, with the primary motivation for its use being to improve riparian habitat, control channel erosion and reduce sediment supply to the channel network (Brooks and Lake, 2007; Lovett and Price, 2007). Increasingly, large wood reintroduction is being employed in conjunction with riparian revegetation, as a means of stabilising banks, reducing bed material transport and improving in-stream habitat availability (Abbe et al., 2003; Brooks et al., 2004; 2006).

A major constraint on recovery efforts is that the extent of rehabilitation work required frequently exceeds the resources available (Rutherfurd and Gippel, 2001; Brooks et al., 2006). In order to maximise the effectiveness of rehabilitation efforts there is a need to recognise spatial variability in river sensitivity and to target rehabilitation efforts to where they will most effectively achieve project goals. Existing literature recognises that the nature and rate of river responses to European disturbance in Australia has varied markedly across space and time (Rutherfurd, 2000). More recent work shows this is also true at the sub-reach scale (Hoyle et al., 2008a).

Determining where rehabilitation is most needed will depend to a certain degree on the project goals, which may be couched in terms of ecology, geomorphology, hydrology, aesthetics or other criteria. This study is based on the principle that the geomorphic template is the logical starting point for river restoration (Ward et al. 2001), as the physical structure of a river (including sediment supply, substrate conditions, channel shape and size, assemblage of geomorphic units, etc.) directly influences the availability 
of both physical and hydraulic habitat, and provides a template for biotic interactions and associations (Southwood, 1977; Newson and Newson, 2000; Thomson et al., 2001). From a geomorphic and ecological perspective, if the primary aim is to reduce the overall supply of sediment to the channel network, then rehabilitation may simply be targeted to zones of high potential sediment mobility.

A number of authors have highlighted how different bank erosion processes dominate in particular parts of a catchment and how vegetation has varying influences on each of these processes (Lawler, 1992; Abernethy and Rutherfurd, 1998; Millar, 2000). This theoretical approach can help identify particular parts of a catchment where vegetation has the greatest potential to effectively stabilise river banks. Classification systems like the River Styles framework (Brierley and Fryirs, 2005), have been developed to help river managers recognise variability in river sensitivity within a catchment, and to develop qualitative models of change trajectories and recovery potential, and hence to provide a means of setting realistic goals for reach-scale rehabilitation. The Sed-Net modelling framework (Prosser et al., 2001) has been used to develop a quantitative assessment of spatial patterns in erosion processes within a catchment and is suitable for estimating average end of catchment sediment loads at a range of spatial scales. In general, this approach is used to help prioritise reaches for rehabilitation, with the aim of reducing the net supply of sediment to the river channel and hence to the basin outlet (Wilkinson et al., 2004; 2005; 2006).

In general rehabilitation prioritisation strategies tend to be focused at the catchment scale, yet the scale at which rehabilitation efforts are currently applied is at a sub-reach scale. While it is possible for frameworks such as Sed-Net to be applied at a small subcatchment scale (Kinsey-Henderson, et al., 2005), the results are reach-averaged (typically at a scale of $10 \mathrm{~s}-100 \mathrm{~s}$ of kms). Reach averaged results provide little insight into the variability of processes within a reach (Bartley et al., 2007), such as which geomorphic units are the primary sources of sediment, yet knowledge of processes at this scale are clearly appropriate for management intervention. Erosion potential within a reach is influenced by the frequency and degree of inundation, flow velocity, height and density of vegetation cover, volume of sediment supply, calibre of surface sediment and the local presence of other geomorphic controls. There is also little appreciation of the extent to which rehabilitation success is likely to vary at the within-reach scale. For example, in most cases it is simply assumed that native revegetation can be implemented uniformly along the river reach and that it will have a beneficial geomorphic (and ecological) effect (though to varying degrees) wherever it is applied. The same may be said for the reintroduction of large woody debris into the low flow channel. What is not well articulated is that within any particular reach, there are some areas that are more likely to be ongoing sources of sediment, including both fine materials eroded from the banks and coarser materials eroded from bedload stores.

The primary focus of this study is to develop a method using LiDAR data, along with a freely available 1-D hydraulic model, in order to investigate how sediment remobilisation potential varies spatially, under different flow conditions, within a $10 \mathrm{~km}$ study reach of the Upper Hunter River, New South Wales. This approach is designed to complement catchment-scale prioritisation methods. While LiDAR surveys will not be affordable for 
all rehabilitation projects, we argue that the cost (AUD $\$ 30,000$ for this study) is relatively small when compared with current rehabilitation expenditure on many rivers, or indeed what needs to be spent on rehabilitation. For example, AUD \$368,000 in cash contributions plus approximately $\$ 400,000$ in in-kind contributions has been spent on revegetation and large woody debris installation the Upper Hunter study reach between 2004 and 2007 (a conservative estimate based on Keating et al., 2008), and rehabilitation in this reach is certainly far from complete. Furthermore, LiDAR is now being routinely acquired by all levels of government, and is likely to become widely available and at low cost in the near future. The method is developed incorporating a 1-D model to make the approach more accessible to river managers. The aim of this investigation is not to quantify bedload transport rates, if it were, a 2- or 3-D model would be more appropriate. However, as a targeting tool, a 1-D model is believed to be adequate.

\section{Study Reach Setting}

The Upper Hunter study reach is located $5 \mathrm{~km}$ south-west of Muswellbrook draining an area of $4220 \mathrm{~km}^{2}$ (Figure 1). The reach is an alluvial low-moderate sinuosity gravel-bed river with a 10 - $40 \mathrm{~m}$ wide low flow channel inset within a larger 75 - 600m wide macrochannel (sensu van Niekerk et al., 1995; Figure 1) with an average channel gradient of 0.0014 . Reach scale post-European settlement disturbances, affecting the availability of sediment within the reach, as well as the supply of sediment and flow from upstream, have produced a complex within-reach response, including the highly variable macrochannel width. This is largely due to a range of inherited landscape controls, including buried terrace material and bedrock outcrops (Hoyle et al., 2008a). Historically, riverworks in this reach have largely been reactive, and those that have attempted to be proactive have failed to recognise these localised controls and their influence on withinreach sensitivity (Hoyle et al., 2008a). The variable macrochannel expansion has resulted in considerable within-reach variability in channel cross section and instream geomorphic units (bars, benches etc). This variable morphology is also associated with a spatially variable bedload mix, with varying degrees of sediment organisation (Hoyle et al., 2008b). The variability in substrate, disturbance frequency and access to groundwater has in turn affected the distribution of riparian vegetation.

Hoyle et al (2008a) split the reach into 9 sub-reaches, termed adjustment zones, each classified according to the degree of post-European channel expansion (determined from historical survey information). Low adjustment zones (LAZ, zones 4, 6 and 9) have a macrochannel width of around $75-120 \mathrm{~m}$ (Figure 1) and are characterised by elongate pools within straight reaches that extend up to $1.2 \mathrm{~km}$ long. In contrast, the high adjustment zones (HAZ, zones 1, 3 and 7) have a channel width in excess of $300 \mathrm{~m}$ and are characterised by major channel cut-offs, significant bar deposits and very wide benches (sensu Erskine and Livingstone, 1999). Intermediate adjustment zones (IAZ, zones 2, 5 and 8) have channel widths between $150 \mathrm{~m}$ and $300 \mathrm{~m}$. They contain benches that are, generally, not as wide as the bar deposits and the bar units tend to be more complex than in the HAZ. 
The bed, bars and benches within the macrochannel are comprised of a variable mix of sediments, but dominated by non-cohesive sands and gravels, with varying degrees of organisation. Hoyle et al (2008b) identified seven distinct forms of sediment mix (range of sizes based on the Wentworth scale) and organisation, termed 'surface facies', and presented a conceptual model relating the facies to their location on a bar, geomorphic unit, inundation frequency and formation process (Figure 2). The benches are generally fine, but may comprise a poorly sorted mix of sizes from sand to cobbles, and are often elevated more than three metres above the low flow surface. The main bars are generally made up of wide platforms elevated 2-3 metres above the low flow surface and dissected by ridges, chutes and scour holes each with associated facies. Facies at these locations include those found on the benches, as well as cobbles embedded within fine sand and various sheets of well sorted gravels. Inset lower bars sit just above the low flow surface and comprise well sorted sheets of granules, pebbles or cobbles. These are the only surfaces in the reach that exhibit any patterns of longitudinal sediment sorting (Iseya and Ikeda 1987, Whiting et al. 1988). In some cases the cobbles have been reworked sufficiently to cause imbrication. The low flow channel is composed of an irregularly spaced pool-riffle sequence. The riffles have a surface armour (sensu Whiting and King, 2003), comprised of well sorted cobbles and pebbles, with the occasional small boulder. The pools range in depth from $0.5-4 \mathrm{~m}$ deep and, due to turbidity, the spatial arrangement of surface facies is difficult to determine, however, sizes range from fine sands to the occasional boulder.

Flow gauging data for the Hunter River at Muswellbrook are available from 1907 to date (Figure 3). The completion of Glenbawn Dam, located $11 \mathrm{~km}$ upstream of Aberdeen, in 1958 caused changes in sediment supply and flow regime. Glenbawn Dam occludes approximately $30 \%$ of the catchment and has resulted in increased low flows and decreased peak flows. Under the current flow regime, river flows are $<12 \mathrm{~m}^{3} / \mathrm{s}$ for $90 \%$ of the time, and $<1 \mathrm{~m}^{3} / \mathrm{s}$ for $10 \%$ of the time (Hoyle et al., 2008a). Contemporary morphological bankfull discharge, averaged along the study reach, is approximately 1700 $\mathrm{m}^{3} / \mathrm{s}$, with a recurrence interval of 14 years. The second largest (based on gauge height measurements at Singleton and Maitland), but most destructive flood on record in the Hunter Catchment occurred in February 1955. Gauge cross section changes at the Muswellbrook Bridge Gauge mean that the exact discharge of the 1955 event is unknown, however, a reconstructed hydrograph (figure 3) estimates the discharge to have been around $5680 \mathrm{~m}^{3} / \mathrm{s}$. This event is considered the 1 in 100 year event throughout the Hunter catchment. This event caused little macrochannel expansion in the study reach but mobilised huge volumes of sediment that had been temporarily stored as wide, flat and low lying bars post channel expansion (Hoyle et al., 2008a). Since 1955 there have been 2 events greater than a 1:20 yr event (1971 and 1992) and 11 events greater than a 1:5yr event. The period post 1955 has been one of aggradation within the study reach, with extensive deposition and reworking of bars occurring in the 1970's (Hoyle et al., 2008a).

The riparian margins of the study reach are generally dominated by willows, herbaceous weeds and grasses with pockets of remnant and regenerating native river oaks (Casuarina cunninghamiana). The distribution of these vegetation assemblages is influenced by substrate and access to groundwater, as well as the inundation and disturbance frequency 
(Kyle, 2007). Cropping and intensive agriculture are conducted primarily on the floodplain with grazing on the surrounding hill slopes (Spencer et al., 2004).

\section{Methods}

\section{Modelling Approach}

In order to examine spatial patterns in relative bed material mobility within such a complex reach it was necessary to incorporate data representing the variable morphology, vegetation distribution and substrate into a modelling approach. Much of this data was obtained from a high resolution survey using LiDAR (light detection and ranging; or airborne laser swath (ALS) mapping). ALS mapping involves the collection of laser pulse returns from a plane mounted LiDAR system. The return pulses are classified into first and last returns. Real time kinetic differential GPS coupled with ground control points are used to determine the XYZ co-ordinates for the point of reflection for each laser pulse. An interpolation process is then used to generate a digital elevation model (DEM) that corresponds to the vegetation canopy (first returns) and another DEM that corresponds to the ground (last returns). Included in this processing are algorithms to exclude structures such as farm houses and sheds. LiDAR surveys are becoming widely used to develop DEMs as a basis for 2- and 3-D hydraulic modelling. Such detailed modelling approaches and the software required are not always easily accessible to river practitioners, nor are they always necessary. In this study the widely available 1-D hydraulic model, HEC-RAS (http://www.hec.usace.army.mil/software/hec-ras/hecras-download.html) is used to determine 'relative' sediment entrainment potential. Such a model provides an estimate of local shear stress which may be used to assess the relative potential for sediment mobility at different flows. However, while the 3-D details of roughness and topography can be accounted for using LiDAR data, the same level of detail is unavailable for understanding details of the flow structure. This limits the ability of the model to predict details relating to sediment transport rates. However, the model is sufficient for determining relative sediment mobility, which is useful for understanding reach scale dynamics and targeting rehabilitation efforts. The flowchart presented in Figure 4 summarises the modelling approach used, whilst key aspects of the approach are described in further detail below.

A critical factor in hydraulic modelling is the accuracy of the representation of the river channel and floodplain topography, as this influences both the flood hydraulics and the aerial extent of flood inundation. Horritt and Bates (2001) indicated that topography is more important than process representation for predicting inundation extent and that a simple model may be used to good effect, but that friction coefficients are generally illdefined. Casas et al. (2006) demonstrated that the use of topographic data from highresolution laser altimetry data LiDAR (light detection and ranging), gives greatly improved 1-dimensional hydraulic modelling results compared with DEMs derived from GPS survey and vectorial cartography. They also demonstrated that the more detailed the representation of the terrain model, the greater the sensitivity of the model output to roughness coefficient variation. At present there has been little work on the development of physically-based friction models for use in 1-dimensional hydraulic models. The 
within-reach spatial variability in channel morphology and riparian vegetation in the Upper Hunter study reach presented an opportunity to trial such an approach.

Historically channel roughness, or resistance, has been estimated in a number of different ways, including the use of simple channel descriptions (e.g. Chow, 1988; Henderson, 1966; Petts, 1983) or using photographs of reference reaches with calibrated roughness values (e.g. Barnes, 1967; Hicks and Mason, 1998; Ladson et al., 2003). The limited accuracy of these techniques has been highlighted (e.g. Bray, 1979; Charnley, 1987; Hey, 1972), particularly in highly vegetated channels. The effect of vegetation is perhaps the most difficult component of channel resistance to estimate, as the interactions between flow, fluid properties, and the biophysical properties of the vegetation are complex (Tabacchi et al., 2000). Considerable research has been carried out on flume studies of flow through vegetation (Kouwen, 1988; Kouwen and Fathi-Moghadam, 2000; Kouwen and Li, 1980; Wu et al., 1999), however, extending these results to natural river channels is not simple. Kouwen and $\mathrm{Li}$ (1980) showed that roughness height varies as a function of the amount of drag exerted by the flow. The drag caused by vegetation is affected by a number of factors. The first is the height of the vegetation relative to flow depth. Vegetal roughness has the greatest effect on overall roughness when it is emergent above water surface and, for submerged vegetation, friction reduces as the depth of submergence increases. Secondly, drag is affected by the flexural rigidity of the vegetation. With flexible vegetation, drag is reduced as the vegetation bends with increasing stage and discharge (Kouwen and Unny, 1973). Thirdly, drag is affected by the density of the vegetation (e.g. Petryk and Bosmajian, 1975). Vegetation density, flexibility and degree of emergence or submergence are, therefore, all critical considerations when estimating vegetative roughness, but at present, the knowledge of reasonable $n$ values for each component in natural channels has not been thoroughly investigated (Soong and Hoffman, 2002). In the absence of reference data for appropriate specific vegetation types, the tables presented by Arcement and Schneider (1989) provide reasonable guidance in evaluating channel and floodplain roughness. The tables split vegetative roughness into five categories from small to extreme, with a description and range of potential roughness values given for each category.

\section{LiDAR Derived Digital Elevation Model and Field Verification}

LiDAR data were obtained for this study in winter 2003 and the last pulse laser returns (classified as ground) were used to derive a $1 \mathrm{~m}$ digital elevation model (DEM). Field survey data (including 1100 to 1860 points taken from 3 locations and an additional 17 cross sections) were used to verify the DEM (Cohen et al., 2004). Due to dense vegetation on some surfaces, the DEM was found to overestimate ground elevation by up to $0.30 \mathrm{~m}$ at some sites, with a mean discrepancy of $0.18 \mathrm{~m}$. However, the overall shape of the predicted surface was found to be a good representation. LiDAR data does not capture data below the water surface so additional field survey data was collected at $100 \mathrm{~m}$ intervals in the low flow channel. The DEM was post processed to remove erroneous data and add data from the low flow transects. The final DEM is shown in Figure 1(b). 
Field mapping and analysis of the DEM was used to classify the DEM into floodplain, bank, bench, main bar, lower bar and low flow channel zones (Figures 1, 2 and 5) based on relative elevation and surface substrate (Hoyle et al., 2008b). Identifying these geomorphic units prior to assigning friction values was important because each of these surfaces has a different base roughness, due to its substrate (Figure 2), and the relative elevation of each unit affects the degree to which the vegetation cover is inundated (i.e. submerged or emergent) in each flow event. The post-European settlement adjustment zones were defined based on those used by Hoyle et al. (2008a) and are identified in Figure 1.

\section{LiDAR Derived Vegetation Classification and Field Verification}

LiDAR data layers can also be used to generate maps of vegetation height and density over large areas with a high level of accuracy (depending on the nature of the ground cover) (Cobby et al., 2001; Menenti and Ritchie, 1994). Vegetation height is calculated as the differential between the first and last return. Density is derived from laser return intensity. Intensity is measured during data acquisition, and is defined as the ratio of incoming to out going radiation of a laser pulse. The incoming radiation is the sum of the signal returns. Hard and flat surfaces reflect most of the laser signal. Faceted objects with internal shaded space (such as a leafy tree) will scatter and absorb some portion of the laser pulse. The intensity data received from the data provider had been converted to a relative linear scale of 0 to 255 .

Based on the premise that more dense vegetation canopies must scatter and absorb more electromagnetic radiation, the intensity data was used as a proxy for vegetation density. The intensity values (0-255) were rescaled to 0 to $100 \%$ and incorporated directly into structural vegetation classes as Projective Foliage Cover (PFC). The veracity of using laser intensity data as a proxy for PFC was established through field verification of the structural vegetation classes.

The vegetation height and density data obtained from the LiDAR were used to classify vegetation into structural classes based on a simplified version of Specht (1970). This structural classification scheme for vegetation is based on the height, PFC, and life form of the tallest stratum. This system allows plant communities with essentially the same structural characteristics, in terms of height and density to be grouped. As plant height and density relate to roughness, it follows that the Specht classification system may help with friction parameterisation, aiding in the development of more accurate hydraulic models. The classes used are given in Table 1 and a map of vegetation distribution for a sub-reach is shown in Figure 5.

In the Specht classification, a tree is defined as a woody plant $>5 \mathrm{~m}$ tall, usually with a single stem. A shrub is a woody plant $<8 \mathrm{~m}$ tall and frequently has many stems arising at or near the base. For the purposes of this study several simplifications of the Specht classification were made. Shrubs were not common in the study reach so for simplicity all shrubs were clumped into the height range 1-5 $\mathrm{m}$ and shrubs over $5 \mathrm{~m}$ were considered trees. All vegetation under $1 \mathrm{~m}$ was classed as grass. 
The Specht classes were verified in the field by comparing a series of derived structural classes with the vegetation observed on site. For each Specht class (other than shrubs, where a lack of this class made it impossible) at least 7 sites were visited and the assemblage of vegetation species, height and density were noted. Photographs were taken at each site and tied to GPS locations. These were used to aid in the estimation of roughness values. Field verification showed that the Specht classification was not always consistent with a particular species. Each vegetation class generally comprised a community of various species, and young trees of a particular species generally appeared in a different class to those fully grown. However, the Specht classification was found to be consistent in terms of vegetation structure and was therefore considered a useful system for parameterising roughness.

\section{Assigning Manning's n Values to the Vegetation Classes on Each Geomorphic Unit}

Geomorphic unit and Specht class outlines were combined into one ArcMap shapefile with a different polygon for each Specht class on each unit. The polygons were used to split cross sections into subsections and a value for the roughness coefficient, $\mathrm{n}_{\text {тот }}$, was assigned to each subsection following the approach of Arcement and Schneider (1989). The tables proposed by Arcement and Schneider (1989) were used to estimate values for $\mathrm{m}, \mathrm{n}_{\mathrm{b}}, \mathrm{n}_{1}, \mathrm{n}_{2}$ and $\mathrm{n}_{3}$ for each geomorphic unit (Table 2), and to develop a family of vegetative roughness $\left(\mathrm{n}_{4}\right)$ curves relating Specht class and geomorphic unit at each flow stage, taking into consideration the depth of inundation of each unit and whether vegetation would be submerged or emergent during each flow stage modelled (Figure 6). These components of roughness were then combined to give a total roughness value $\left(\mathrm{n}_{\text {Tот }}\right)$. When assigning values for vegetative roughness, the following generalisations were made:

- There is very little vegetation in the low flow channel, other than patchy macrophytes, therefore vegetative roughness in this location decreases with flood height and is considered negligible above 5 yr ARI.

- Emergent vegetation has greater roughness than submerged vegetation and of the emergent vegetation shorter vegetation has greater roughness than taller vegetation (as trunks are considered to produce less drag than submerged foliage at the study site). For this reason trees on lower bars have greater roughness than trees on higher units for each event.

- When vegetation is submerged, taller vegetation has greater roughness than shorter vegetation, as it influences a greater proportion of the water column.

- The relative roughness on each geomorphic unit changes with flood height as vegetation on each unit becomes increasingly inundated and has a greater or lesser influence on roughness depending on height and structure.

- On the floodplain, the roughness value is constant for events with less than $5 \mathrm{yr}$ RI (as the floodplain isn't inundated by these sized events), tall vegetation remains emergent during all events and therefore all trees are considered equal (with only trunks submerged), and shrubs are considered to have the same roughness as trees for all floods up to the 100 year RI when they become submerged and roughness reduces. 
- Shrubs have uniform density with height and are relatively rigid, therefore they have high roughness when emergent and roughness only reduces when well submerged.

- Grasses are very flexible and therefore roughness reduces significantly with increasing flood height.

The estimation of each of the components of roughness, and particularly the vegetation, involved many approximations and the absolute roughness values may not be accurate. However, the aim was to establish a relative order of roughness using the data available. To allow for the uncertainty involved in the roughness estimation, three roughness data sets were initially developed (minimum, best estimate and maximum) and the values providing the best fit to a calibration event used in the subsequent analysis.

\section{Incorporating LiDAR Data into the HEC-RAS Model}

Hydraulic computations were carried out using HEC-RAS (version 4.0 Beta, USACE, 2006). This is a one-dimensional model for a gradually varied flow regime, solved by the standard step-backwater method (Chow, 1988). HEC-GeoRAS (http://www.hec.usace.army.mil/software/hec-ras/hec-georas_downloads.html) is an ArcGIS extension and was used to generate geometric data, including extracting cross section information from the DEM, which were then imported into HEC-RAS. This extension also imports the hydraulic modelling results back into the GIS, where the intersection between the computed water level at each of 262 cross sections $(\sim 40 \mathrm{~m}$ spacing) and the DEM enabled mapping of the flood extent and spatial analysis of the results.

A range of different flood scenarios were modelled based on 1 year to 100 year ARI discharges. These discharges were calculated using a Log Pearson III distribution of the annual maximum discharge data for the period post Glenbawn Dam closure (Figure 2). The discharges modelled are given in Table 3.

\section{Model Calibration}

The largest flood to occur during this study had a discharge of $370 \mathrm{~m}^{3} / \mathrm{s}$. This discharge falls between the 2 and 3 year ARI (Table 3) and resulted in inundation of all bar and partial inundation of most bench units throughout the study reach. To calibrate the model, peak flow stage data at 97 locations spread along the length of the study reach, as well as continuous stage data (collected at 5 minute intervals) from 2 stage recorders (Figure 1) were compiled and compared with modelled stage data. The average difference between the observed and the modelled stage heights (using best estimate roughness) was $0.18 \mathrm{~m}$, which equates to the mean accuracy of the DEM (see above). An Analysis of Variance (ANOVA) showed that these data were not statistically different ( $F<\mathrm{F}_{\text {crit }}$; Table 4). 12 of the 97 calibration locations had observed-modelled discrepancies greater than $0.4 \mathrm{~m}$ and these sites were investigated more thoroughly to determine whether alteration of specific roughness classes would improve model output. These sites were found to be either localised areas of significant vegetative growth in the period since the collection of the 
LiDAR data or locations on the outside of sharp bends where superelevation may have occurred (and therefore process representation is the limiting factor). No flows inundated the floodplain during this study and therefore it wasn't possible to calibrate the model for overbank flows, however, a greater than bankfull event (20 year ARI) occurred in 2000 and peak flood height was measured at one point midway down the reach by a landholder. The modelled stage height for this event (using best estimate roughness) was less than the measured value by $0.19 \mathrm{~m}$. It is acknowledged that one measurement point does not constitute sufficient validation; however, the differences between the modelled and observed stage heights for these two events are consistent and considered to be within the accuracy of the DEM and peak flood stage measurement. Therefore the parameterised best estimate roughness values were considered to adequately represent roughness distribution and were used for the remainder of the modelling exercise.

\section{Predicting Short-Term Variability in Relative Surface Sediment Mobility}

Water surface elevation output from HE-GeoRAS was related to the underlying channel topography (from the DEM) in order to calculate the distribution of water depths through the study reach during the various flood scenarios. The channel cross section, gradient and distribution of water depth could then be used to calculate the spatial distribution of depth averaged velocities within the macrochannel. Distribution of depth averaged velocity, $U$, was then converted to a distribution of shear velocity near the bed, $u^{*}$, using Equation 2 (Wilcock, 1996):

$$
u_{*}=\frac{U}{\frac{1}{K} \ln \left(\frac{d}{e z_{0}}\right)}
$$

Equation 2.

Where $K$ is von Karman's constant, taken to be 0.4 , $d$ is the depth of water in metres and $\mathrm{z}_{0}$ is the bed roughness. Shear velocity at a site is relatively sensitive to bed roughness and therefore mobility of sediment on the various geomorphic units is confounded by the role of vegetation in protecting the surface. However, as the roughness due to vegetation has already been accounted for when modelling the water depth and depth averaged velocity distribution, the role of vegetation was not considered again at this point. Bed roughness is taken to be $D_{84} / 10$ (Whiting and Dietrich, 1990), and values for $D_{84}$ were based on a simplified representation of the known distribution of sediment facies throughout the reach (Hoyle et al., 2008b). In order to relate the shear velocity distribution to sediment entrainment potential, it was necessary to calculate the critical shear velocity required to mobilise various sediment mixes. When shear velocity at a site exceeds the critical shear velocity of a particular sediment size or mix then that sediment has potential to be mobilised. To calculate critical shear velocity, the dimensionless critical shear stresses for each sediment size or mix are calculated. To assess the spatial variability in sediment mobilisation potential within the reach, critical shear stresses were calculated for deposits varying in calibre from sand to boulder (based on the Wentworth scale). The sediment mixes that comprise the surface facies in the study reach vary in terms of their dominant size, with some areas being dominated by sand, others by gravel and others being bimodal. Therefore, to determine the critical shear stresses required to mobilise each of the existing surface facies in their entirety various critical shear stress 
equations were used depending on the typical sediment mix at each unit, following the approach of de Linares and Belleudy (2007).

The dimensionless critical shear stress, $\tau_{c i}^{*}(1)$, required to mobilise sediment of size faction $i$ in a mixture where sand is dominant and there is essentially no gravel present was calculated using Equation 3 (de Linares and Belleudy, 2007):

$$
\tau_{c i}^{*}(1)=\tau_{c s m}^{*}(1) \frac{D_{s m}}{D_{i}} \quad \text { Equation } 3 .
$$

Where $\tau_{\text {csm }}^{*}(1)$ is the dimensionless critical shear stress required to mobilise $D_{50}$ (clast size of which $50 \%$ of the sample is smaller) of sand. In the absence of bedload transport measurements in this reach we adopted the calibrated value of 0.066 used by de Linares and Belleudy (2007). $D_{s m}$ is the $D_{50}$ of sand in metres. $D_{i}$ is the grain size of fraction $i$, which was taken to be $D_{84}$. The dimensionless critical shear stress, $\tau^{*}{ }_{c i}(0)$, required to mobilise sediment of size fraction $i$ in a mixture where gravel is dominant and there is essentially no sand present was calculated using Equation 4 (de Linares and Belleudy, 2007):

$$
\tau_{c i}^{*}(0)=\tau_{c g m}^{*}(0) \frac{D_{g m}}{D_{i}}
$$

Equation 4.

Where $\tau_{\text {cgm }}^{*}(0)$ is the dimensionless critical shear stress required to mobilise $D_{50}$ of gravel, for which the calibrated value of 0.043 used by de Linares and Belleudy (2007) was adopted. $D_{g m}$ is the $D_{50}$ of gravel in metres. For locations where gravel clasts sit exposed on a sand dominant mixture, $\tau^{*}{ }_{c i}(1)$ was calculated using Equation 5 (de Linares and Belleudy, 2007):

$$
\tau_{c i}^{*}(1)=\tau_{c s m}^{*}(1)\left[\frac{\ln (30.3 c)}{\ln \left(30.3 c \frac{D_{i}}{D_{s m}}\right.}\right]^{2}
$$

Equation 5.

Where $\mathrm{c}$ is the ratio relating the relative height that the hydrodynamic force is applied to the grain in question and was taken to equal 0.3, as found by de Linares and Belleudy (2007). For locations where the sediment mix was bimodal, $\tau_{c i}{ }_{c i}$ was calculated using Equation 6 (de Linares and Belleudy, 2007):

$$
\tau_{c i}^{*}=\tau_{c i}^{*}(1)+\left[\tau_{c i}^{*}(0)-\tau_{c i}^{*}(1)\right] e^{-14 F_{s}} \quad \text { Equation } 6 .
$$

Where $F_{s}$ is the proportion of sand in the mixture (with 0 for no sand and 1 for all sand). In each case the dimensionless critical shear stress was converted to critical shear stress, $\tau_{c}$, using Equation 7 and the critical shear stress converted to critical shear velocity, $u_{c}^{*}$, using Equation 8 (Buffington and Montgomery, 1997):

$$
\begin{aligned}
\tau_{c}=\tau_{c i}^{*} /\left(\rho_{s} / \rho\right) g D_{i} & \text { Equation } 7 . \\
u_{c}^{*}=\left(\tau_{c} / \rho\right)^{1 / 2} & \text { Equation } 8 .
\end{aligned}
$$


The data required to calculate the critical shear velocities for the varying bed materials are given in Table 5 .

Within reach variability in shear velocity was examined using shear velocity distribution maps. These distribution maps highlight differences in shear velocity within and between geomorphic units at individual sites, also showing zones that are not inundated (only relevant for the smaller events). The shear velocity distribution was split into classes to normalise results and highlight spatial trends. This classification was based on the calculated critical shear velocity values for varying bedload calibre (sand-boulder, see Table 5). A simple statistical analysis of the shear velocity distribution maps was also undertaken to emphasise any general spatial trends in sediment mobility throughout the reach. This analysis involved calculating the proportional area of the different geomorphic units in each zone comprised of the different shear velocity classes for each flood event modelled. This highlights general differences in the modal (dominant) size of maximum mobile sediment between the various units and zones as flood event increases. For example, if the modal sediment size is pebble then that is the maximum size mobile across the majority of the unit in question.

The final step in this study was to use the contemporary distribution of sediment mixes in the study reach (based on the findings of Hoyle et al., 2008b) to calculate the critical shear velocity distribution for the reach. These results were then related to the modelled shear velocities to identify zones with high relative potential for sediment entrainment. This is intended to be a short term prediction only, as changes in the surface sediment, vegetation cover or channel morphology will influence future sediment mobility.

\section{Results}

\section{Within-Reach Variability in Sediment Mobility}

The results from this investigation use spatial variability in shear velocity within a complex reach to infer how bedload mobility might vary spatially during a range of discharges. The inherent uncertainties in modelling mean that the predicted sizes of mobile sediment presented in the results may vary from our predictions; however the relative mobility of different surfaces can still be used to highlight spatial patterns and help prioritise rehabilitation efforts.

During the modelled 1 year event $\left(8 \mathrm{~m}^{3} / \mathrm{s}\right)$ many, but not all, of the lower bars, are inundated but none of the main bars or benches are. These lower bars are generally zones of deposition, as the shear velocity is not great enough to mobilise sand. Differences between pools and riffles are particularly clear during this size event (Figure 7), with the pools being zones of deposition. These pools include the long pools that make up the entire LAZ, as well as the shorter pools in the IAZ and HAZ. Small calibre sediment (sand and granules on the Wentworth scale) is mobile in the riffles, with pebbles only mobile in the steeper parts of the riffle. The mobile sediment in the reach is unlikely to 
travel very far during events of this magnitude, due to the lack of longitudinal connectivity of the mobile zones through the reach.

The 2 year event $\left(260 \mathrm{~m}^{3} / \mathrm{s}\right)$ has a discharge significantly greater than the 1 year event and the vast majority of the lower and main bars are inundated. Connectivity of mobile sediment increases significantly throughout the reach, with sand and granules mobile throughout these lower units. The pools become more mobile (carrying sediment to pebbles size) than the riffles (some carrying pebbles, but many only granules). The low bars have similar sediment mobility to the riffles. The mobility of sediment on the main bars ranges from nothing mobile to mobile pebbles (Figure 8), with typical high mobility at the downstream apex of these units (Figure 7). Parts of many of the benches are also inundated but dense grass cover and limited water depth (and thus low flow velocity) means sediment is largely immobile.

Spatial variability in sediment mobilisation potential between bars becomes particularly apparent during floods between a 2 and 5 year ARI. Low bars become clearly more mobile than the main bars, but there are also differences between main bars, as some are more than a metre higher above the low flow than others. In a 5 year ARI event (780 $\mathrm{m}^{3} / \mathrm{s}$ ) all bars and most benches are inundated. The benches are still largely areas where the threshold of mobility has not been exceeded (Figure 7). The main bars become much more mobile with the proportional area of mobile pebbles on these units increasing between the 2 and 5 year ARI from 10 to $30 \%$ in the HAZ and 20 to $37 \%$ in the IAZ (Figure 8). Pebbles become mobile in at least $60 \%$ of the low flow channel and across 95\% of low bars in the LAZ. Pebbles still have limited mobility in riffles, however, in some parts of the long pools (LAZ) cobbles start to become mobile. The statistical analysis presented in Figure 8 shows that less than $10 \%$ of the low flow channel is competent to transport cobbles in a 10 year event $\left(1300 \mathrm{~m}^{3} / \mathrm{s}\right)$, and Figure 7 clearly shows this area of mobility to be focused in the LAZ. These cobbles are likely to accumulate in the riffles downstream in zones 5 and 7, where the macrochannel widens and flow energy is subsequently reduced.

Significant changes in sediment mobility on the low bars of the LAZ occur during floods between the 5 and 10 year ARI. In a 5 year event no cobbles are mobile on these units, yet they become potentially mobile across greater than $50 \%$ of the surface by the 10 year event. In the remainder of the reach, the surface area of benches with zero mobility (considered likely deposition areas) shrink from 69 \% (HAZ) and $54 \%$ (IAZ) to $35 \%$ and $21 \%$ respectively, and gain significant areas of mobile sand and granules.

Between the 10 and 20 year event (2000 $\left.\mathrm{m}^{3} / \mathrm{s}\right)$ flow becomes overbank throughout the reach. The statistics show little change in the size of sediment mobile on each unit (generally less than 10\% surface area increase for the larger mobile calibre in each case), but clear changes are apparent on the benches, particularly in the HAZ (Figure 7). In the 20 year event there is also increased mobility of cobbles in the shorter pools.

As flows increase beyond the 20 year event the area of mobility on the benches increases significantly (for example $23 \%$ increase in area with mobile granules in the HAZ and 21 
$\%$ increase for pebbles in the IAZ) indicating that the benches are essentially zones of deposition between a 5 and 20 year event but at flows greater than this they start to become sources of finer bedload. In both the $50\left(3150 \mathrm{~m}^{3} / \mathrm{s}\right)$ and $100\left(4200 \mathrm{~m}^{3} / \mathrm{s}\right)$ year events cobbles become mobile in the riffles, low bars, and on parts of the main bars. Throughout all modelled flows, boulders never become mobile in the reach, indicating that the small boulders observed in some parts of the reach are perhaps originated from local basal lag material or, in the case of the pools, perhaps nearby rock revetment works.

\section{Highlighting Zones of Potential Erosion During the Next Major Event}

The slight difference in sediment mobility between the HAZ and IAZ shown in the previous section is accentuated in the potential mobility maps (Figure 9). These maps display the difference between the shear velocity and critical shear velocity (based on contemporary surface facies distribution) throughout the reach, helping to highlight local 'hot spots' for potential erosion. Zones where the shear velocity is greater than the critical shear velocity required to mobilise the facies currently at that site are classified as zones of 'potential erosion', whereas areas where the shear velocity is less than the critical shear velocity are classified as zones of 'no erosion'. To highlight locations that may be particularly susceptible to erosion, the 'potential erosion' zones have been arbitrarily split based on the degree to which the critical shear velocity is exceeded. Zones where the shear velocity is greater than critical shear velocity but the difference is less than that required to mobilise sand (0.033) are termed 'low risk', with the remainder 'high risk'.

These results indicate a clear difference between the benches of the HAZ and IAZ, which becomes most apparent between the 10 and 20 year ARI (Figure 9). In a 10 year event the benches tend to include large 'no erosion' areas as well as zones of 'low risk' potential erosion. The proportional area subject to this 'low risk' potential erosion is greater in the IAZs. The IAZ benches also have small areas of 'high risk' potential erosion, but this is not widespread during the 10 year event. In the 20 year event the HAZs retain large areas of 'no erosion' but the area of 'low risk' potential erosion has spread significantly. Isolated areas of 'high risk' potential erosion are particularly apparent at the upstream end of the benches. The greatest change occurs in the IAZs, which have a much greater proportional area subject to 'high risk' potential erosion during these events, and greatly reduced 'no erosion' zones.

The main bars appear to remain immobile throughout the reach for all flood events, due to the large $\mathrm{D}_{84}$ of sediment typically found on the surface of these units. There are only isolated areas of 'low risk' potential erosion (and occasionally 'high risk' potential erosion) apparent on the upstream and outside edge of these bars. However, based on the results presented in the previous section, sediment of pebbles size and smaller could be transported over, or potentially winnowed from, these units during events of a 10 year ARI and greater. There could also be significant deposition of finer gravels on these units during smaller events, filling the interstices or even completely burying the existing distribution of cobbles. In the low flow channel the long pools that comprise the LAZ are clearly zones of 'high risk' potential erosion for all flood events greater than a 5 year ARI. However, the presence of geological controls in these zones would play a 
significant role in limiting the extent of actual erosion. In the low flow channel of the IAZ and HAZ, the shorter pools become mobile at a 10 year ARI and the riffles are zones of 'no erosion' for events less than the 50 year ARI. The low bars are very similar to the riffles with widespread potential erosion typically only occurring in the 50 and 100 year events, with a small degree of variation throughout the reach.

\section{Discussion}

\section{Variable Within-Reach Sensitivity to Bedload Entrainment}

The magnitude-frequency relationship for sediment mobility in this study reach has been shown to be complex, with the relative mobility of sediment not solely controlled by elevation above the low flow channel (or relative frequency of inundation). The potential mobility of the various geomorphic units is also influenced by the variation in channel geometry, vegetative roughness and the contemporary calibre of surface sediment. While it may be true that within any adjustment zone sediment of a given size becomes less mobile with increasing elevation, this relationship is not directly reflected by the contemporary surface sediment distribution. The surface sediment on each unit instead records a historic sequence of events, and has been influenced by spatial variability in morphology and vegetation cover, which has changed significantly over time (Hoyle et al., 2008b).

It is acknowledged that as the size of sediment on a surface changes due to future events, so too will the shear velocity and the potential mobilisation of different sediment sizes from and over those surfaces. The timeframe over which this analysis remains relevant will depend on the sequence and geomorphic effectiveness of future floods, and the feedbacks between sediment composition, vegetation community structure, hydraulic roughness and channel morphology. However, for the purposes of analysing near term spatial patterns for sediment remobilisation potential, the surface facies distribution is a necessary starting point. Even if the spatial distribution of surface facies changes in the near future, the relative mobility of different surfaces is expected to hold, and the model can be rerun with relatively minor adjustments to the input parameters.

\section{Where is Rehabilitation Needed Most?}

The scope of this paper is to identify zones that have a high potential for sediment entrainment, in order to prioritise rehabilitation in a way that will reduce sediment yield. However, deciding the degree and nature of bedload erosion that is acceptable in any given location will be influenced to a degree by project goals, including management timeframes and ecological priorities. The results of this investigation show that some locations, both at the sub-reach (adjustment zone) and geomorphic unit scale, are far more prone to future erosion than others. Hence, this study demonstrates that the resolution of analysis undertaken here is clearly appropriate for gaining an understanding of reach dynamics that are appropriate for the design of a rehabilitation strategy. 


\section{At the Sub-Reach Scale}

The LAZs have the highest excess shear velocity and are zones of 'high risk' potential erosion. However, field investigations and historic analysis has shown that the actual risk of bank erosion or extensive channel incision in the long pools of the LAZ, or on the outside of many bends in the IAZ, is limited by the presence of local geological controls (Hoyle et al., 2008a). This reduces the overall rehabilitation priority (Figure 10). When comparing the IAZs with the HAZs, the results clearly show that the IAZs are at greater risk of erosion. We propose an analogy between the Adjustment Zones of this reach and typical reaches at the catchment scale, in terms of the spatial variability in erosion potential. In many catchments, as a general rule, confined bedrock channels are found in the headwaters, partly confined (or semi-alluvial) channels in the middle reaches and unconfined (or alluvial) channels in the lowland reaches. While, the upper reaches of a catchment have the highest energy, valley confinement limits the capacity for the channels to adjust. This is similar to the limited potential for erosion in the LAZs of this reach. The morphology of alluvial and semi-alluvial rivers are largely controlled by the same variables, however semi-alluvial rivers typically have discontinuous floodplain pockets that are prone to reworking (Nanson, 1986; Nanson and Croke, 1992), due to the minimal capacity of these reaches to dissipate the energy of large floods as overbank flows. This, along with the fact that they are generally located in higher energy, steeper parts of the catchment and tend to have less cohesive (i.e. weaker) banks, means that semi-alluvial channels are often more dynamic than alluvial channels and more likely to be eroded (Brooks, 2003). While channel gradient and bank material is essentially the same in the IAZ and HAZ (Hoyle et al., 2008a), the greater confinement of the IAZs means they are more limited in their capacity to dissipate flood energy and results show they are more prone to bench erosion.

\section{At the Geomorphic Unit Scale}

The pools in the study reach, particularly the long pools of the LAZ have the highest potential for erosion, and while erosion of the banks is prevented by bedrock control, any bedload stored in these pools is readily mobilised. Hence, while the pools are typically accumulating fine sediment under low flow conditions, they are readily flushed during flows greater than 2 year ARI. The relative ease of sediment mobility and the relatively uniform geometry in the LAZ pools, has resulted in a distinct lack of bedform heterogeneity. This, along with the lack of riparian vegetation and instream wood, means there is a very limited range of habitat in these locations, and rehabilitation works could be targeted to mitigate this.

In contrast to the pools, significant erosion of the riffles requires a flood greater than the 20 year ARI event. Infrequent bedload turnover in these locations may actually be considered a problem from an ecological perspective, as the interstices of the coarse surface armour can become clogged with fine sediments interrupting hydrologic exchange and nutrient transfer between the surface water and the hyporheic zone (sensu Schalchli, 1992; Boulton, 2007). The low bars of the reach have relatively high potential for erosion and may be considered a high rehabilitation priority; however, these units are relatively small sources of sediment supply and they also occur within the area occupied by the pre-European channel. Indeed, it is possible that these deposits represent the type 
of bar deposit that was mobile within the pre-European channel (Figure 10). The main bars in the reach are shown to be at low risk of erosion.

By far the greatest potential source of sediment in the reach is from the benches. These are large stores and comprise a high proportion of sands and silts, which are a potential threat to instream habitat if remobilised. These benches are essentially an inset floodplain and indicate a certain degree of river recovery has occurred since the major flood of 1955 (Erskine, 1992). These are valuable stores of sediment in rivers like the Upper Hunter, where the long term upstream supply of sediment is extremely limited. It is important that these benches are encouraged to build and that any erosion is limited. The results from this study show that these units will likely be zones of 'no erosion' and potential deposition for events smaller than a 20 year ARI, but that many benches, and particularly the upstream and outside edge of benches, are at risk of erosion in larger events. Vegetation cover would be of great benefit to these units in terms of increasing roughness and thereby reducing erosivity (Darby and Thorne, 1992), as well as increasing bank cohesion (Millar, 2000). However, revegetation success will vary, and it is possible that vegetation may also be stripped from benches during very large events (Anderson, 2006).

\section{Where and What Type of Rehabilitation is Likely to Have Greatest Success?}

Over the last decade, an explosion of research into the ecological and geomorphological functions and benefits of wood in streams (e.g. Gregory et al., 2003; Cottingham et al., 2003; Lovett and Price, 1999; 2007) has meant that the reintroduction of wood into low flow channels as a rehabilitation technique is gaining considerably in popularity (e.g. Brooks, 2006; Brooks et al., 2004; 2006). While manuals such as that of Brooks (2006) can provide guidance about how to increase the likelihood of success of in-stream wood reintroduction projects, there is currently little data on the relative long term success of wood installed in different locations, or indeed how to prioritise reintroduction locations. Relative mobility data derived using the methodology proposed here are clearly valuable for such projects, as they can be used in the design of in-stream structural measures, and more importantly, can be used to identify in-stream erosion hotspots to ensure the most effective use of scarce rehabilitation dollars. In circumstances where it is deemed that it is necessary to undertake major rehabilitation works, the cost of performing an analysis such as the one presented here is well within the scope of the design work typically required for a major restoration/rehabilitation project.

In terms of riparian zone revegetation, rehabilitation success depends on both the ability of vegetation to reduce sediment yield and on revegetation survivorship. A review of the revegetation program carried out in the Upper Hunter River Rehabilitation Initiative (UHRRI) study reach (the same reach under investigation in this study) showed marked differences in both survivorship between species and on different geomorphic units (Keating et al, 2007). While overall revegetation survivorship was low, due to drought conditions, higher survivorship was recorded at many sites in those areas closest to the low flow channel and at higher elevations such as higher benches or floodplain typically containing deeper, heavier textured soil (Figure 10). Highest mortality was experienced upon the lower alluvial surfaces containing coarser, free draining substrate. Although a 
range of reasons probably contributed to the observed pattern, low soil moisture retention is likely to be a key factor (Keating et al, 2007). As indicated in Figure 10, there is a strong correlation between the locations where there is greatest need to reduce sediment mobility and locations in which revegetation is likely to have the greatest survivorship success.

While quantifying the role of different vegetative structure in protecting different surfaces is outside the scope of this investigation, we can infer from existing literature that the success of different vegetative structure will vary depending on location. This is largely influenced by the type of sediment the vegetation is 'protecting'. For instance, the benefits of vegetation on stream banks is largely provided by the fact that tree roots are able to enhance bank shear strength (Abernethy and Rutherfurd, 1998), and therefore deep rooted vegetation is likely to be most successful. Within the macrochannel, rigid vegetation (trees and shrubs) has the ability to increase hydraulic resistance and therefore reduce the erosivity of flow (Anderson et al., 2006). The degree of resistance provided is influenced by the density of vegetation and its height relative to water depth. Therefore, to provide benefit across a range of different flood magnitudes would require vegetation of varying heights. Grasses have been shown to effectively control channel width (Rutherfurd, 2007) in streams of a certain size, and can act to decrease channel width, by trapping fine sediment (Thorne, 1990). This has particular relevance on the benches. However, this protection is only provided as long as the erosive potential of the stream is less than that required to scour the grass (Marsh et al., 2004; Rutherfurd, 2007). The establishment of trees and shrubs on these units is important for reducing flow velocity and prevent the scour of grass. However, as it is important that grass cover is maintained on these units to protect the fine substrate, the density of the taller vegetation needs to be low enough that it does not result in bare soil. Further research that quantifies the effect of varying vegetation structure in encouraging deposition (and preventing erosion) on varying substrates would help improve rehabilitation targeting approaches like that recommended here.

\section{Conclusion}

This investigation shows that the intermediate adjustment zones in the reach are at greater risk of erosion than the other sub-reaches. The geomorphic units at greatest risk of bedload erosion are the benches, low bars and short pools of the intermediate and high adjustment zones. The benches and low bars are also units that have been shown to have the highest rates of revegetation survivorship, which further emphasises the need to target rehabilitation to these units. Due to the volume of the sediment stored within the benches, and the broader objective of encouraging channel contraction towards its pre-disturbance state (sensu, Brooks and Brierley, 2004), it is important that erosion of these units is limited, and indeed, deposition encouraged. These units are recommended as the highest priority for rehabilitation, in particular the upstream and outside margins. The reintroduction of wood back into the low flow channel, through the introduction of engineered log jams, is also recommended, to improve bank stability, increase the diversity of physical and hydraulic habitat, and improve hyporheic exchange. 
This study has highlighted the value of using LiDAR data to parameterise the topography and roughness layers for the widely available HEC-RAS hydraulic modelling framework in order to prioritise river rehabilitation efforts at the sub-reach scale. While the LiDAR data still appears to be a relatively expensive option from which to derive a reach scale topographic model, it is becoming more routinely collected by government agencies, and the benefits one gets from its acquisition pays significant dividends compared with traditional on-ground topographic and vegetation survey techniques. Indeed, our experience suggests that it is cheaper in the longer term than traditional approaches, more accurate, and more spatially representative. The approach outlined can also be adapted to undertake a broad range of hydro-ecological and geomorphic scenario simulations, which can shed light on many more system interactions of proposed and actual rehabilitation works, than those presented here. Hence, the initial investment involved in setting up a model such as this, can be justified on the basis that it can perform multiple roles in the design and evaluation of river rehabilitation programs. With increasing resources being directed towards river rehabilitation efforts globally, particularly targeting sediment supply reduction and improving the ecological condition of channels and riparian corridors, there is an increasing need for approaches such as this that can provide funding agencies with greater confidence that public resources are being wisely spent. The approach outlined here is appropriate for reaches which have been identified in a catchment scale assessment as priorities for more intensive management intervention. An analysis such as this can not only provide the basis for designing a reach scale rehabilitation strategy, but it can provide important insights into the variability of processes within a reach at a scale that is appropriate for management intervention. We argue that despite the apparent expense of an exercise such as this, at high value strategic rehabilitation sites, the upfront expenditure on this kind of analysis is money well spent. This kind of analysis provides an alternative to a full 2D or 3D modelling exercise that typically will be undertaken, at greater expense, as part of an engineering design at strategic rehabilitation sites.

\section{Acknowledgements}

We would like to thank AAM Hatch for provision of the LiDAR data; Harley Betts and Tim Cohen, for their work in helping to develop and verify the DEM; Jeff Shellberg for his valuable advice on hydrologic data and analysis; Dan Keating, for his support and extensive help in the field, including the verification of vegetation distribution data and help in flood level marking; Alex Spink, Erika Heiden and Kirstie Fryirs for their help in surveying in flood heights; and Gary Brierley for his advice on research that has provided a background to this investigation. We also thank Rebecca Bartley and two anonymous reviewers for valuable comments on an earlier version of this paper. This work is funded by an Australian Research Council Linkage Grant with support from the following industry partners; Macquarie Generation, Bengalla Mine, Mt Arthur Coal, Department of Natural Resources, Department of Lands and Hunter and Central Rivers Catchment Management Authority. Thanks also to local landholders for their support and unlimited access to the Hunter River study site. 


\section{References}

Abbe TB, Brooks AP, Montgomery DR. 2003. Wood in river rehabilitation and management. In The Ecology and Management of Wood in World Rivers, Gregory SV, Boyer KL, Gurnell AM. (eds), American Fisheries Society. Bethesda; 367389.

Abernethy B, Rutherfurd I. 1998. Where along a river's length will vegetation most effectively stabilise stream banks? Geomorphology 23: 55-75.

Anderson, B. G., I. D. Rutherfurd, et al. (2006). "An analysis of the influence of riparian vegetation on the propagation of flood waves." Environmental Modelling \& Software 21(9): 1290-1296.

Arcement GJ, Schneider VR. 1989. Guide for selecting Manning's roughness coefficients for natural channels and flood plains. US Geological Survey Water Supply Paper 2339.

Barnes HH. 1967. Roughness characteristics of natural channels. US Geological Survey Water Supply Paper 1849: 1-213.

Bartley R, Post D, Kinsey-Henderson A, Hawdon A. 2007. Estimating sediment loads in Great Barrier Reef catchments: balance between modelling and monitoring. In: Wilson AL, Dehaan RL,Watts RJ, Page KJ, Bowmer KH, Curtis A (eds), Proceedings of the 5th Australian Stream Management Conference. 13-18.

Bernhardt ES, Palmer MA, Allan JD, Alexander G, Barnas K, Brooks S, Carr J, Clayton S, Dahm C, Follstad-Shah J, Galat D, Gloss S, Goodwin P, Hart D, Hassett B, Jenkinson R, Katz S, Kondolf GM, Lake PS, Lave R, Meyer JL, O'Donnell TK, Pagano L, Powell B, Sudduth E. 2005. Ecology: Synthesizing US river restoration efforts. Science 308(5722): 636-637.

Bond NR, Lake PS. 2003. Local habitat restoration in streams: constraints on the effectiveness of restoration for stream biota. Ecological management and restoration 4(3): 193-198.

Boulton AJ. 2007. Hyporheic rehabilitation in rivers: restoring vertical connectivity. Freshwater Biology 52(4): 632-650.

Bray DI.,1979. Estimating average velocity n gravel-bed rivers. Journal of the Hydraulics Division, ASCE, HY9: 1103-1122.

Brierley G, Fryirs K. 2005. Geomorphology and River Management: Applications of the River Styles Framework. Blackwell Publishing, Oxford.

Brooks AP. 2003. A conceptual model of geomorphic changes to catchments and river channels in southeastern Australia since European settlement: causes and implications. Airs, Waters, Places Transdisciplinary Research in Ecosystem Health, University of Newcastle, Callaghan, NSW.

Brooks AP. 2006. Design guideline for the reintroduction of wood into Australian streams, Land and Water Australia, Canberra.

Brooks AP, Brierley GJ. 1997. Geomorphic responses of lower Bega River to catchment disturbance, 1851-1926. Geomorphology 18: 291-304.

Brooks AP, Brierley GJ. 2004. Framing realistic river rehabilitation targets in light of altered sediment supply and transport relationships: lessons from East Gippsland, Australia. Geomorphology 58(1-4): 107-123. 
Brooks AP, Gehrke P. Jansen JD, Abbe TB. 2004. Experimental reintroduction of woody debris on the Williams River, NSW: geomorphic and ecological responses. River Research and Application 20; 513-536.

Brooks AP, Howell T, Abbe TB, Arthington A. (2006). Confronting hysteresis: wood based river rehabilitation in highly altered riverine landscapes of south-eastern Australia. Geomorphology 79: 395-422.

Brooks SS, Lake PS. 2007. River restoration in Victoria, Australia: Change is in the wind, and none too soon. Restoration Ecology 15(3): 584-591.

Buffington JM, Montgomery DR. 1997. A systematic analysis of eight decades of incipient motion studies, with special reference to gravel-bedded rivers. Water Resources Research 33(8): 1993-2030.

Bunn S, Davies PM, Kellaway DM. 1997. Contributions of sugar cane and invasive pasture grass to the aquatic food web of a tropical lowland stream. Marine and Freshwater Resources, 48: 173-179.

Casas A, Benito G, Thorndycraft V, Rico M. 2006. The topographic data source of digital terrain models as a key element in the accuracy of hydraulic flood modelling. Earth Surface Processes \& Landforms 31: 444-456.

Charnley PR. 1987. Lowland Drainage. In River Engineering. Part 1, Design Principles, Brandon TW. (ed), The Institution of Water Engineers and Scientists, London; 173-224.

Chow VT. 1988. Open Channel Hydraulics. International edition. McGraw Hill, London.

Cobby DM, Mason DC, Davenport IJ. 2001. Image processing of airborne scanning laser altimetry for improved river flood modelling. ISPRS Journal of Photogrammetry and Remote Sensing 56(2): 121-138.

Cohen T, Brooks A, Samosorn B. 2004. The potential of airborne laser scanning (ALS) data to produce detailed surveys of rivers: An example from the Upper Hunter River, New South Wales, Australia. In Australian Stream Management Conference, Rutherfurd I, Wiszniewski I, Askey-Doran M, Glazik R. (eds), Launceston, Tasmania; 154-158.

Cottingham P, Bunn S, Price P, Lovett S. (eds) 2003. Managing wood in streams, River and Riparian Land Management Technical Guideline, no. 3. Land and Water Australia, Canberra.

Darby SE, Thorne CR. (1992). Simulation of near bank aggradation and degradation for width adjustment models. Falconer, R.A. Shiono, K. \& R.G.S. Matthew. Hydraulic and Environmental Modelling: Estuarine and River Waters, Cambridge. University Press: 431-441.

de Linares M, Belleudy P. 2007. Critical shear stress of bimodal sediment in sand-gravel rivers. Journal of Hydraulic Engineering 133(5): 555-559.

Douglas G, Palmer M, Caitcheon G. (2003). The provenance of sediments in Moreton Bay, Australia: a synthesis of major, trace element and $\mathrm{Sr}-\mathrm{Nd}-\mathrm{Pb}$ isotopic geochemistry, modelling and landscape analysis. Hydrobiologia 494(1-3): 145152.

Erskine WD. 1992. Channel response to large-scale river training works: Hunter River, Australia. Regulated Rivers 7: 261-278. 
Erskine WD, Livingstone EL. 1999. In-channel benches: the role of floods in their formation and destruction on bedrock-confined rivers. In Varieties of Fluvial Form, Miller AJ, Gupta A (eds), John Wiley and Sons, New York; 445-476.

Fryirs K, Brierley G. 2001. Variability in sediment delivery and storage along river courses in Bega catchment, NSW, Australia. Geomorphology 38: 237-265.

Gregory SV. Boyer KL, Gurnell AM. (eds). The ecology and managemnt of wood in world rivers, American Fisheries Society, Symposium 37, Bethesda, Maryland.

Henderson FM. 1966. Open Channel Flow. Macmillan, London.

Hey RD. 1972. An analysis of some of the factors influencing the hydraulic geometry of river channels. PhD Thesis, University of Cambridge.

Hicks DM, Mason PD. 1998. Roughness Characteristics of New Zealand Rivers. Water Resources Survey, DSIR Marine and Freshwater, Wellington, New Zealand.

Hillman M, Brierley G. (2005). A critical review of catchment-scale stream rehabilitation programmes. Progress in Physical Geography 29(1): 50-76.

Horritt MS, Bates PD. 2001. Predicting floodplain inundation: raster-based modelling versus the finite-element approach. Hydrological Processes 15: 825-842.

Hoyle JT, Brooks A, Brierley G, Fryirs K, Lander J. 2008a. Variability in the nature and timing of channel response to typical human disturbance along the Upper Hunter River, New South Wales, Australia. Earth Surface Processes \& Landforms 33: 868-889, DOI: 10.1002/esp.1580.

Hoyle JT, Brierley G, Brooks A, Fryirs K. 2008b. Sediment organisation along the Upper Hunter River, Australia: a multivariate statistical approach. In Gravel Bed Rivers 6 - from Process Understanding to River Restoration, Habersack H, Piegay H, Rinaldi M. (eds), Elsevier, Amsterdam; 409-441

Iseya F, Ikeda H. 1987. Pulsations in bedload transport rates induced by a longitudinal sediment sorting: a flume study using sand and gravel mixtures. Geografiska Annaler 69A: 15-27.

Keating DT, Spink A, Brooks AP, Sanders MD, Miller CJ, Leishman M, Fryirs K. 2007. The Upper Hunter River Rehabilitation Initiative: Riparian revegetation and reintroduction of large woody debris (2003 - 2007). Department of Physical Geography, Macquarie University, North Ryde, NSW.

Kinsey-Henderson AE, Post DA, Prosser IP. 2005. Modelling sources of sediment at subcatchment scale: An example from the Burdekin catchment, North Queensland, Australia. Mathematics and Computers in Simulation 69(1-2): 90-102.

Kouwen N. 1988. Field estimation of the biomechanical properties of grass. Journal of Hydraulic Engineering, ASCE 26(5): 559-568.

Kouwen N, Fathi-Moghadam M. 2000. Friction factors for coniferous trees along rivers. Journal of Hydraulic Engineering, ASCE 126(1): 732-740.

Kouwen N, Li RM. 1980. Biomechanics of vegetative channel linings. Journal of the Hydraulics Division, ASCE 106(6): 1085-1103.

Kouwen N, Unny TE. 1973. Flexible roughnesses in open channels. Journal of the Hydraulics Division, ASCE 99(HY5): 713-728.

Kyle G. 2007. Functional plant traits and riparian rehabilitation in a degraded river system. Unpublished PhD Thesis, Macquarie University, NSW, Australia. 
Ladson A, Lang S, Anderson B, Rutherfurd I. 2003. An Australian Handbook of Stream Roughness Coefficients, 28th Hydrology and Water Resources Symposium, The Institution of Engineers Australia, Wollongong, NSW.

Lawler DM. 1992. Process dominance in bank erosion systems. Lowland Floodplain Rivers. Carling PA, Petts GE. Chichester, Wiley: 117-143.

Lovett S, Price P. (eds) 1999. Riparian Land Management Guidelines, volumes 1 and 2. LWRRDC, Canberra.

Lovett S, Price P. (eds) 2007. Principles for Riparian Lands Management, Land and Water Australia, Canberra.

Marsh N, Rutherfurd I, Bunn S. 2004. How does riparian revegetation affect suspended sediment in a southeast Queensland stream? Cooperative Research Centre for Catchment Hydrology Technical Report 04/13.

McKergow LA, Prosser IP, Hughes AO, Brodie J. (2005). Sources of sediment to the Great Barrier Reef World Heritage Area. Marine Pollution Bulletin 51(1-4): 200211.

Menenti M, Ritchie JC. 1994. Estimation of effective aerodynamics roughness of Walnut Gulch watershed with laser altimeter measurements. Water Resources Research 30(5): 1329-1337.

Millar RG. 2000. Influence of bank vegetation on alluvial channel patterns. Water Resources Research 36(4): 1109-1118.

Naiman RJ, Bunn SE, Nilsson C, Petts GE, Pinay G, Thompson LC. 2002. Legitimizing fluvial ecosystems as users of water: an overview. Environmental Management 30:455-467.

Nanson GC. 1986. Episodes of vertical accretion and catastrophic stripping; a model of disequilibrium flood-plain development. Geological Society of America Bulletin 97(12): 1467-1475.

Nanson GC, Croke JC. 1992. A genetic classification of floodplains. Geomorphology 4(6): 459-486.

Nanson GC, Erskine WD. 1988. Episodic Changes of Channels and Floodplains on Coastal Rivers in New South Wales. In Fluvial Geomorphology of Australia, Warner RF. (ed), Academic Press Australia; 201-222.

Newson MD, Newson CL. 2000. Geomorphology, ecology and river channel habitat: mesoscale approaches to basin-scale challenges. Progress in Physical Geography 24: 195-217.

Page KJ, Carden YR. 1998. Channel adjustment following the crossing of a threshold: Tarcutta Creek, southeastern Australia. Australian Geographical Studies 36(3): 289-311.

Petryk S, Bosmajian G. 1975. Analysis of flow through vegetation. Journal of the Hydraulics Division, ASCE, 101(HY7): 871-884.

Petts GE. 1983. Rivers, Butterworths, London.

Pitlick J, Wilcock P, 2001. Relations between streamflow, sediment transport, and aquatic habitat in regulated rivers. Geomorphic Processes and Riverine Habitat Water Science and Application, 4: 185-198.

Prosser I, Rustomji P, Young W, Moran C, Hughes A. 2001. Constructing River Basin Sediment Budgets for the National Land and Water Resources Audit. CSIRO Land and Water Technical Report 15/01 2001. 
Rutherfurd ID. 2000. Some human impacts on Australian stream channel morphology. In River management the Australasian experience, Brizga SO, Finlayson BL. (eds), Wiley, Chichester; 11-49.

Rutherfurd ID. 2007. The influence of riparian management on stream erosion. In Principles for riparian lands management, Canberra, Lovett S, Price P. (eds.), Land and Water Australia; 85-116.

Rutherfurd ID, Gippel C. (2001). Australia versus the World: do we face special opportunities and challenges in restoring Australian streams? Water Science and Technology 43(9): 165-174.

Schalchli U. (1992). The Clogging of Coarse Gravel River Beds by Fine Sediment. Hydrobiologia 235: 189-197.

Soong TW, Hoffman MJ. 2002. Effects of riparian tree management on flood conveyance study of Manning's roughness in vegetated floodplains with an application on the Embarras River in Illinois, Illinois State Water Survey Watershed Science Section. A Division of the Illinois Department of Natural Resources, Champaign, Illinois.

Southwood TRE. 1977. Habitat, the templet for ecological strategies? The Journal of Animal Ecology 46: 336-365.

Specht RL. 1970. Vegetation. In The Australian Environment, Leeper GW. (ed), CSIRO Australia and Melbourne University Press; 44-67.

Spencer J, Fryirs K, Keating D, Brierley G. 2004. River styles in the upper Hunter catchment. Department of Physical Geography, Macquarie University, North Ryde, NSW.

Tabacchi E, Lambs L, Guilloy H, Planty-Tabacchi AM, Muller E, Decamps H. 2000. Impacts of riparian vegetation on hydrological processes. Hydrological Processes 14(16-17): 2959-2976.

Thomson JR, Taylor MP, Fryirs K, Brierley G. 2001. A geomorphological framework for river characterisation and habitat assessment. Aquatic Conservation: Marine and Freshwater Ecosystems 11: 73-389.

Thorne CR. 1990. Effects of vegetation on riverbank erosion and stability. Vegetation and Erosion. Thornes JB (ed), John Wiley and Sons Ltd: 125-144.

U.S.A.C.E. 2006. HEC-RAS, version 4.0 Beta, Hydrologic Engineering Centre, Davis, California.

van Niekerk AW, Heritage GL, Moon BP. 1995. River classification for management: the geomorphology of the Sable River in the eastern Transvaal. South African Geographical Journal 77: 68-76.

Wallbrink PJ, Martin CE, Wilson CJ. 2003. Quantifying the contributions of sediment, sediment-P and fertiliser-P from forested, cultivated and pasture areas at the landuse and catchment scale using fallout radionuclides and geochemistry. Soil and Tillage Research, 69(1-2): 53-68.

Ward JV, Tockner K, Uehlinger U, Malard F. 2001. Understanding natural patterns and processes in river corridors as the basis for effective river restoration. Regulated Rivers: Research \& Management 17: 311-323.

Wasson RJ, Olive LJ, Roswell CJ. 1996. Rates of erosion and sediment transport in Australia. In Erosion and Sediment Yield: Global and Regional Perception, Walling DE, Webb BW. (eds), IAHS Publication; 139 -148. 
White LJ, Rutherfurd I, Hardie RE. 1999. On the cost of stream management and rehabilitation in Australia. Proceedings of the Second Australian Stream Management Conference, Adelaide: 697-703.

Whiting PJ, Dietrich WE, Leopold LB, Drake TG, Shreve RL. 1988. Bedload sheets in heterogeneous sediments. Geology 16: 105-108.

Whiting PJ, Dietrich WE. 1990. Boundary shear stress and roughness over mobile alluvial beds. Journal of Hydraulic Engineering 116(12): 1495-1511.

Whiting PJ, King GJ. (2003). Surface particle sizes on armoured gravel streambeds: effects of supply and hydraulics. Earth Surface Processes and Landforms 28: 1459-1471.

Wilcock PR. 1996. Estimating bed shear stress from velocity observations. Water Resources Research 32(11): 3361-3366.

Wilkinson S, Jansen A, Watts R, Read A, Davey B. 2005. Techniques for targeting erosion control and riparian rehabilitation in the Mount Lofty Ranges. CSIRO Land and Water Client Report.

Wilkinson S, Jansen A, Watts R, Read A, Miller T. 2004. Techniques for targeting protection and rehabilitation of riparian revegetation in the middle and upper Murrumbidgee catchment. CSIRO Land and Water Technical Report, No. 37/04.

Wilkinson SN, Prosser IP, Hughes AO. 2006. Predicting the Distribution of Bed Material Accumulation Using River Network Sediment Budgets. Water Resources Research, 42(10).

Wu FC, Shen HS, Chou YJ. 1999. Variation of roughness coefficients for unsubmerged and submerged vegetation. Journal of Hydraulic Engineering, ASCE 125(9): 934942. 


\section{Table captions}

Table 1 . The system used in classifying vegetation for this investigation, based on a simplified Specht (1970) classification.

Table 2 Components of roughness used to estimate values of Manning's $n$ for each geomorphic unit - vegetation component $n_{4}$ was parameterised based on height and density of vegetation and depth of inundation, therefore $\mathrm{n}_{\text {total }}$ varies spatially and for each flood event.

Table 3 - Modelled discharges representing a range of potential flood event scenarios

Table 4 - ANOVA test of statistical significance of differences between modelled and measured stage heights of calibration event.

Table 5. Critical shear velocity required to mobilise bedload sheets of specific calibre (appropriate values for $\mathrm{D}_{84}$ and $\mathrm{D}_{50}$ were assumed and are stated) and each of the surface facies identified in the reach by Hoyle et al (2008b) $\left(D_{84}\right.$ and $D_{50}$ values measured in the field). $\tau_{c i}{ }_{c i}(1)$ is the dimensionless critical shear stress required to mobilise sediment of size faction $i$ in a mixture where sand is dominant, $\tau^{*}{ }_{c i}(0)$ is the equivalent where gravel dominates, and $\tau^{*}{ }_{c i}$ (bimodal) is for a bimodal surface sediments. In each case the dimensionless critical shear stress is converted to critical shear stress, $\tau_{c}$, and the critical shear stress converted to critical shear velocity, $u_{c}{ }_{c}$

\section{Figure captions}

Figure 1. (a) The location of the study reach within the Upper Hunter and greater Hunter catchment, (b) the location of bar, bench and low flow channel within the macrochannel of the study reach displayed over the $1 \mathrm{~m}$ DEM. High, Intermediate and Low Adjustment Zones (HAZ, IAZ and LAZ respectively) are also indicated, (c) a typical cross section of the study reach in a zone that has undergone postEuropean settlement expansion. The various geomorphic units are identified with the typical height of inundation for various sized flood events indicated.

Figure 2. Typical distribution of sediment mixes within a bar of the study reach - adapted from Hoyle et al (2008b).

Figure 3. Hydrograph for the Muswellbrook Bridge gauge 1907 - 2006. This monthly maximum flow record was reconstructed utilising flow data from the Muswellbrook Weir gauge to improve inaccurate data at the bridge during the 1950's and 1960's, resulting from flood induced cross section changes. Changes in the recurrence interval of significant floods as a result of the closure of Glenbawn Dam are indicated.

Figure 4. Flowchart summarising the key steps taken in this investigation. A full description of the surface sediment facies, the methodology involved in 
classification and the conceptual model relating the facies to specific locations and proposed formation processes are given in Hoyle et al (2008b) and are therefore not detailed in this manuscript.

Figure 5. An example subreach showing geomorphic unit outlines, adjustment zones and the distribution of vegetation height and density. The height and density data were used to identify 20 different vegetation classes using the Specht classification system (Table 1).

Figure 6. 'Best Estimate' vegetative roughness curves used for the 1, 5 and $100 \mathrm{yr}$ ARI flow scenarios. It should be noted that some vegetation classes on some units are redundant in this reach (eg. All vegetation in the low flow channel and tall vegetation on lower bars), however the methodology used indicates relative roughness for such classes if they did exist, and they are retained in this figure for completeness.

Figure 7. The distribution of shear velocity within the macrochannel with increasing flood event.

Figure 8. Trends in shear velocity across geomorphic units and adjustment zones with increasing flood event. Shear velocity has been classified to represent the maximum size of mobile sediment, based on critical shear velocity of the Wentworth sediment classes. The LAZ only indicates low flow and low bar units as main bar and bench units are not present in these adjustment zones.

Figure 9. Predicted areas of 'no erosion', 'low risk and 'high risk' potential erosion during modelled flood events.

Figure 10. Proposed rehabilitation priorities targeted at the geomorphic unit scale, where $\mathrm{H}$ is high priority, $\mathrm{M}$ is moderate priority and $\mathrm{L}$ is low priority. A) priorities based on modelled erosion risk and spatial distribution of geomorphic controls, B) priorities based on spatial variability in revegetation survivorship and predicted access to groundwater (modified from Keating et al, 2007), and C) overall proposed rehabilitation priority considering model results, survivorship results and other ecological considerations. This cross section is representative of an intermediate adjustment zone, but relative priorities are also applicable to high adjustment zones. 


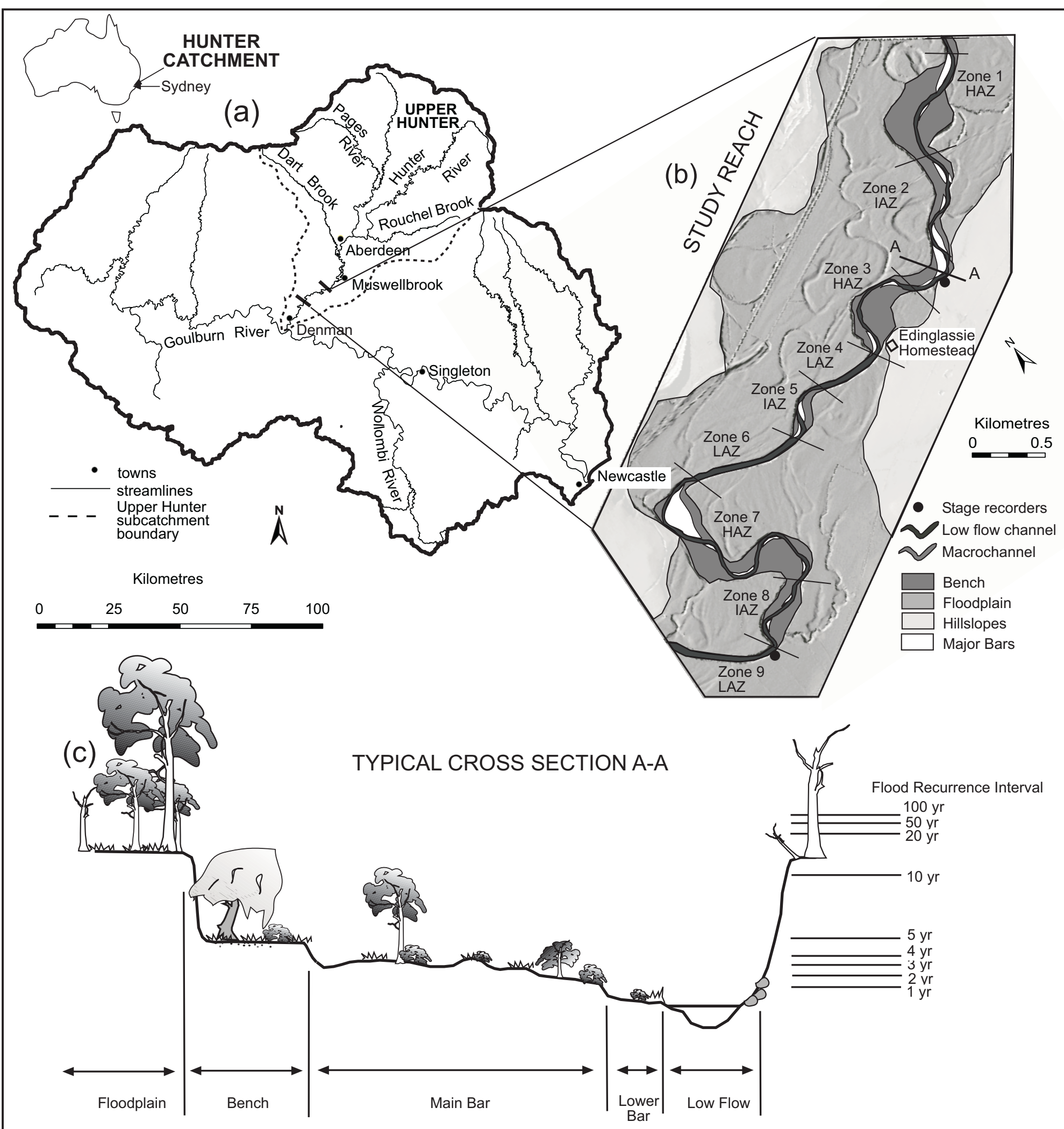




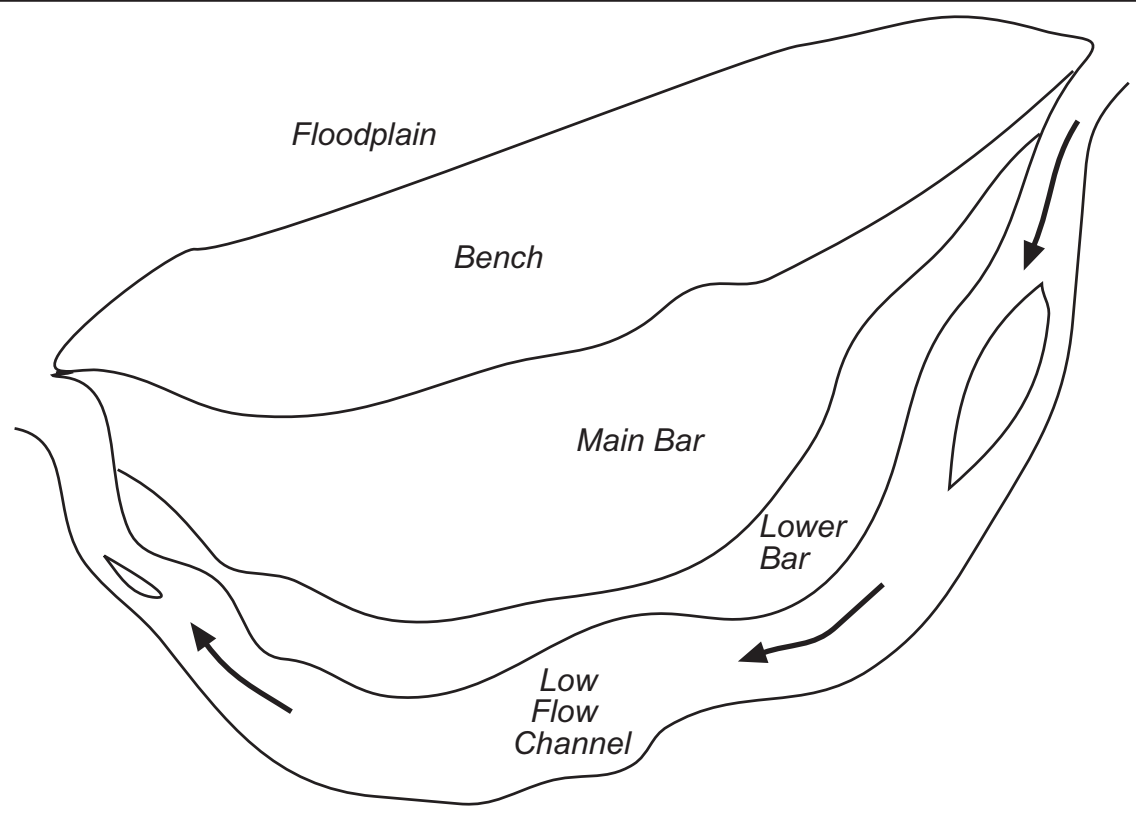

\begin{tabular}{|c|c|}
\hline & Facies \\
\hline $1 \mathrm{a}$ & well sorted massive sands \\
\hline $1 b$ & $\begin{array}{l}\text { well sorted, matrix supported } \\
\text { sands and granules }\end{array}$ \\
\hline $2 a$ & $\begin{array}{l}\text { poorly sorted, clast supported } \\
\text { cobbles embedded in fines }\end{array}$ \\
\hline $2 b$ & $\begin{array}{l}\text { poorly sorted, matrix supported } \\
\text { pebbles and cobbles }\end{array}$ \\
\hline $3 a$ & $\begin{array}{l}\text { censored clast supported } \\
\text { cobbles and pebbles }\end{array}$ \\
\hline $3 b$ & $\begin{array}{l}\text { censored clast supported } \\
\text { loose pebbles and granules }\end{array}$ \\
\hline $3 c$ & $\begin{array}{l}\text { censored and reworked } \\
\text { cobbles and small boulders }\end{array}$ \\
\hline
\end{tabular}

Very Infrequent Inundation
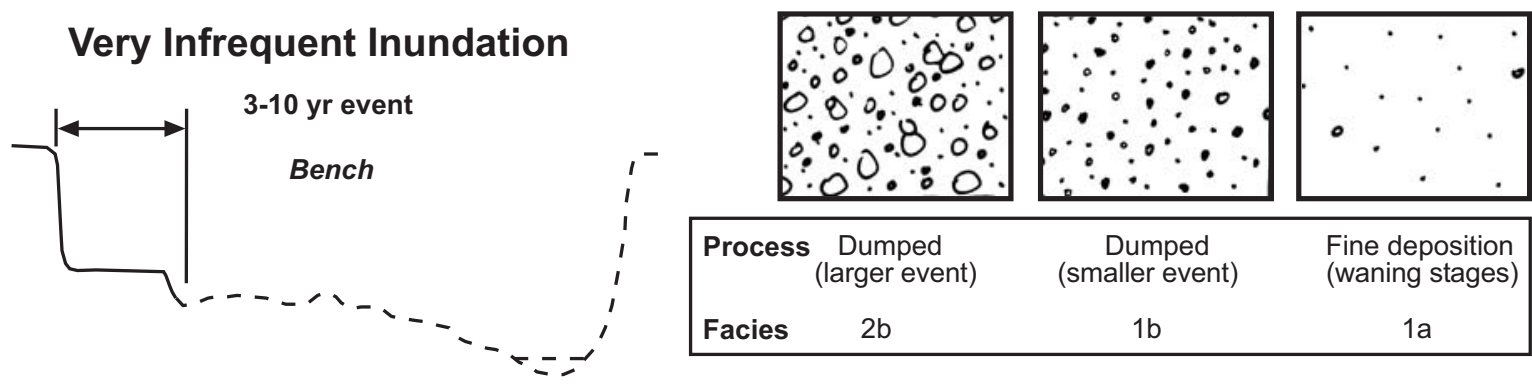

\begin{tabular}{|cccc|}
\hline Process & $\begin{array}{c}\text { Dumped } \\
\text { (larger event) }\end{array}$ & $\begin{array}{c}\text { Dumped } \\
\text { (smaller event) }\end{array}$ & $\begin{array}{c}\text { Fine deposition } \\
\text { (waning stages) }\end{array}$ \\
Facies & $2 \mathrm{~b}$ & $1 \mathrm{~b}$ & $1 \mathrm{a}$ \\
\hline
\end{tabular}

Infrequent Inundation
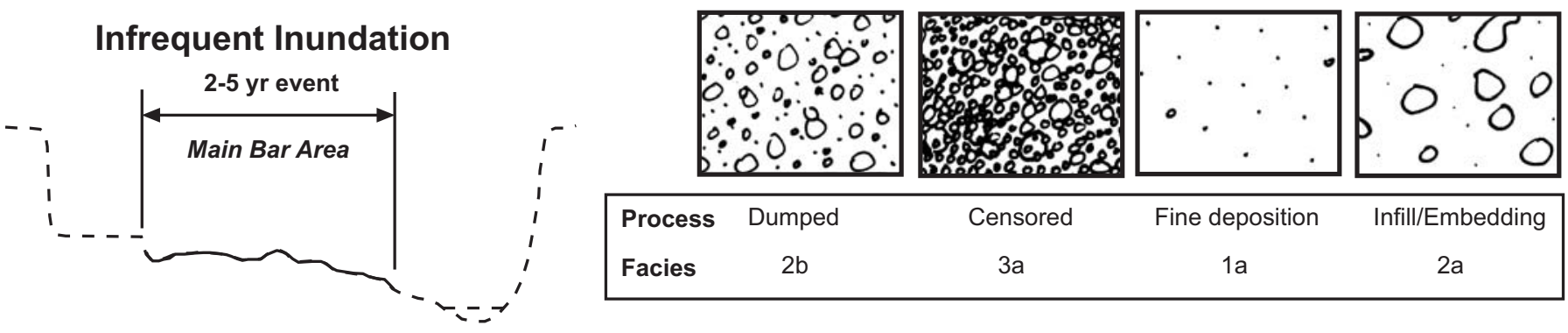

\begin{tabular}{|lcccc|}
\hline Process & Dumped & Censored & Fine deposition & Infill/Embedding \\
Facies & $2 \mathrm{~b}$ & $3 \mathrm{a}$ & $1 \mathrm{a}$ & $2 \mathrm{a}$ \\
\hline
\end{tabular}
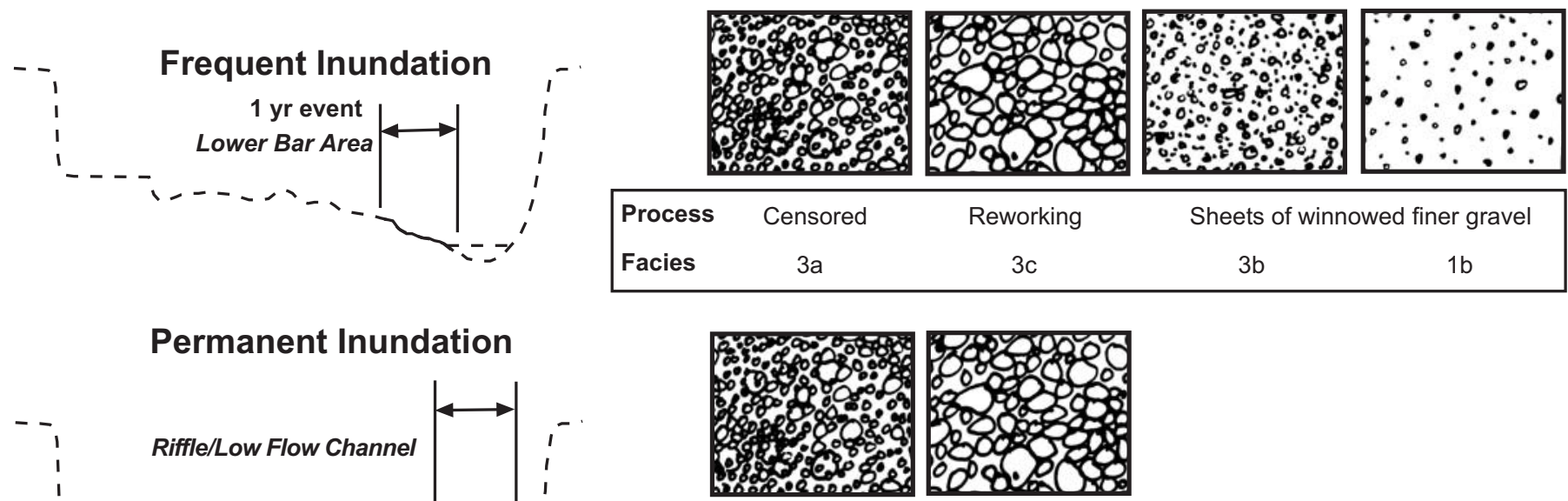

Permanent Inundation

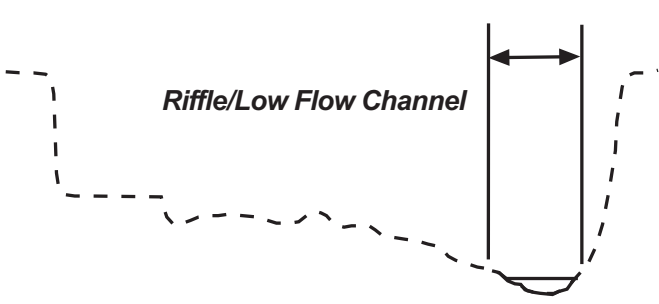

\begin{tabular}{|lcc|}
\hline Process & Censored & Reworked \\
Facies & $3 a$ & $3 c$ \\
\hline
\end{tabular}




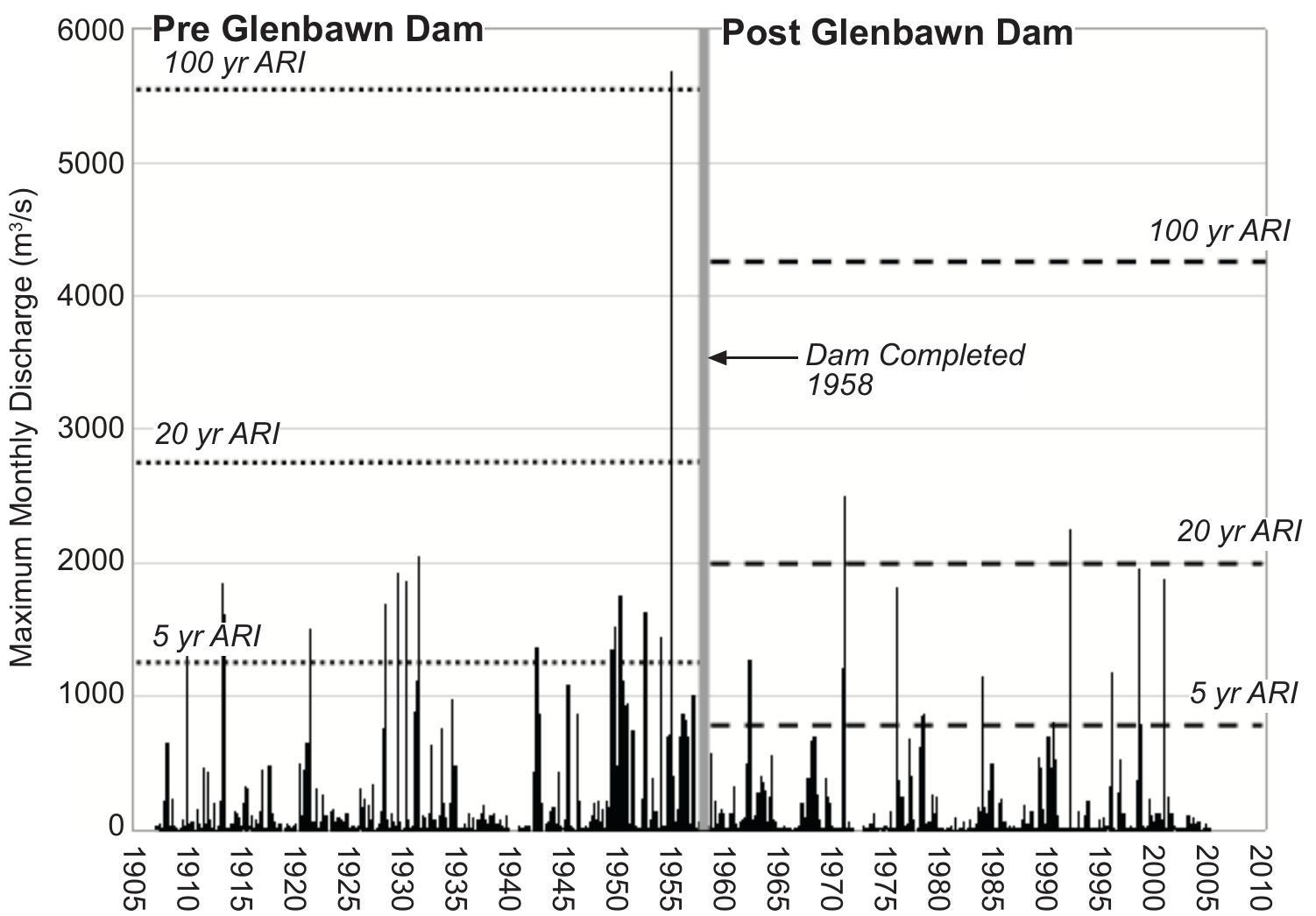




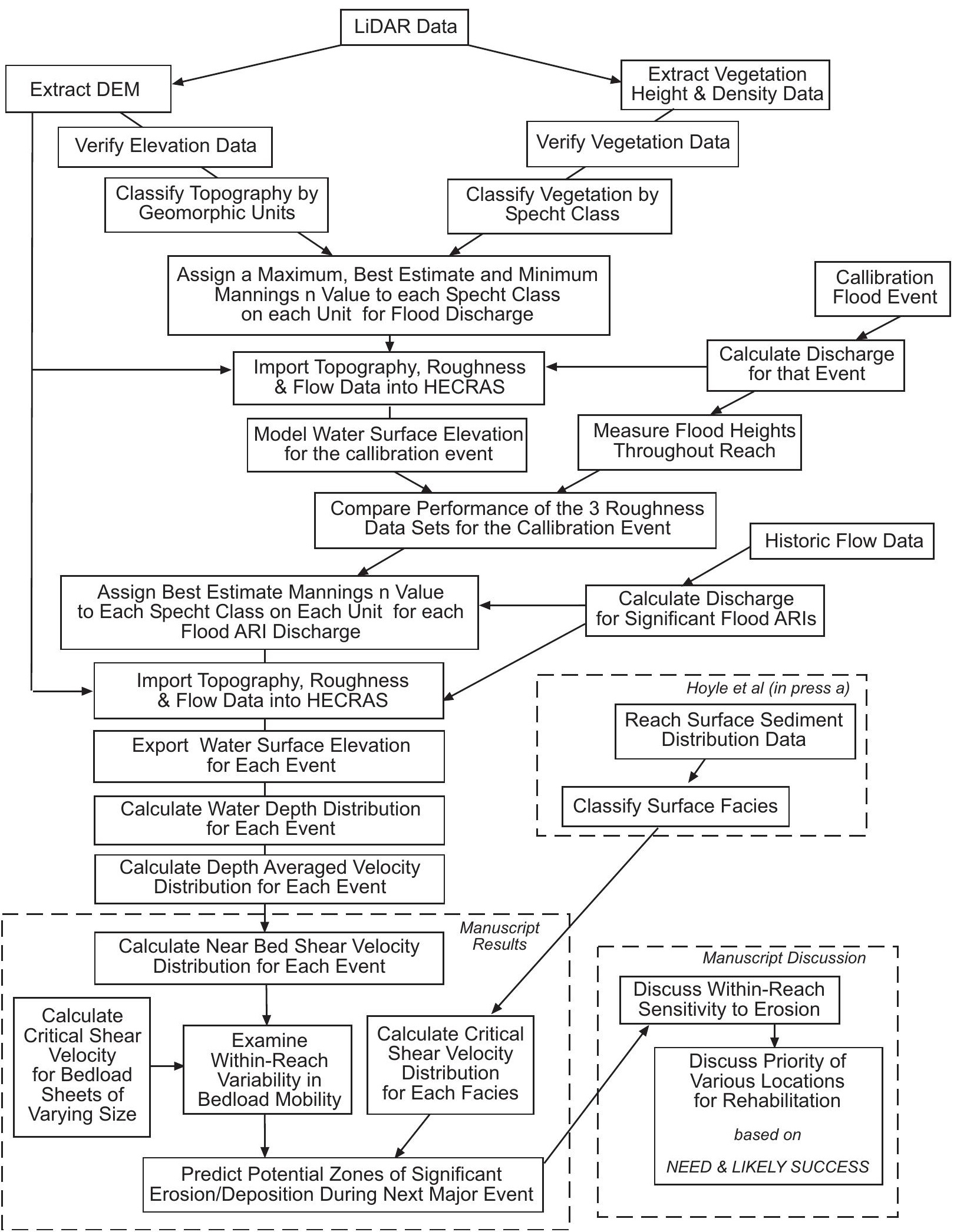




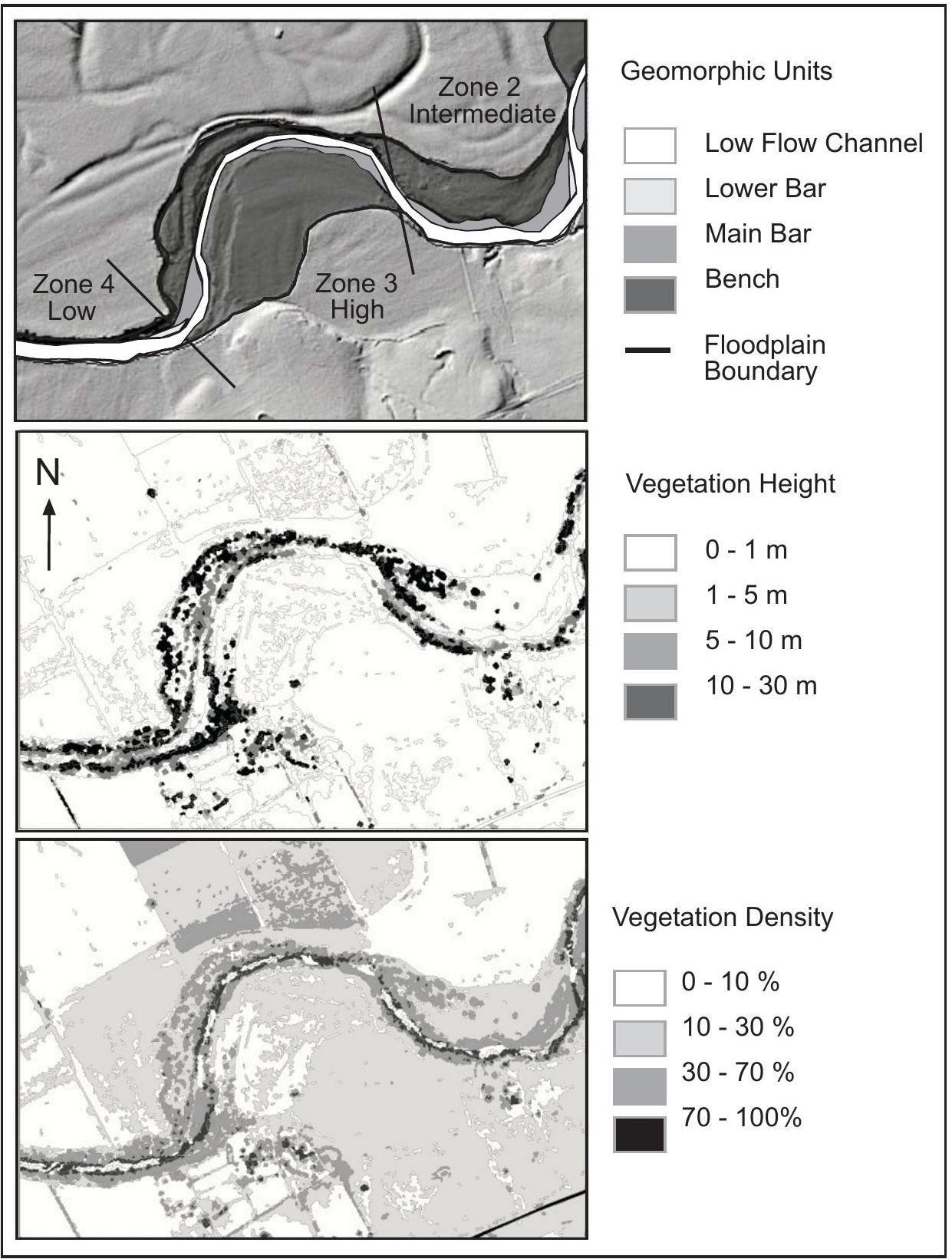


Manning's n

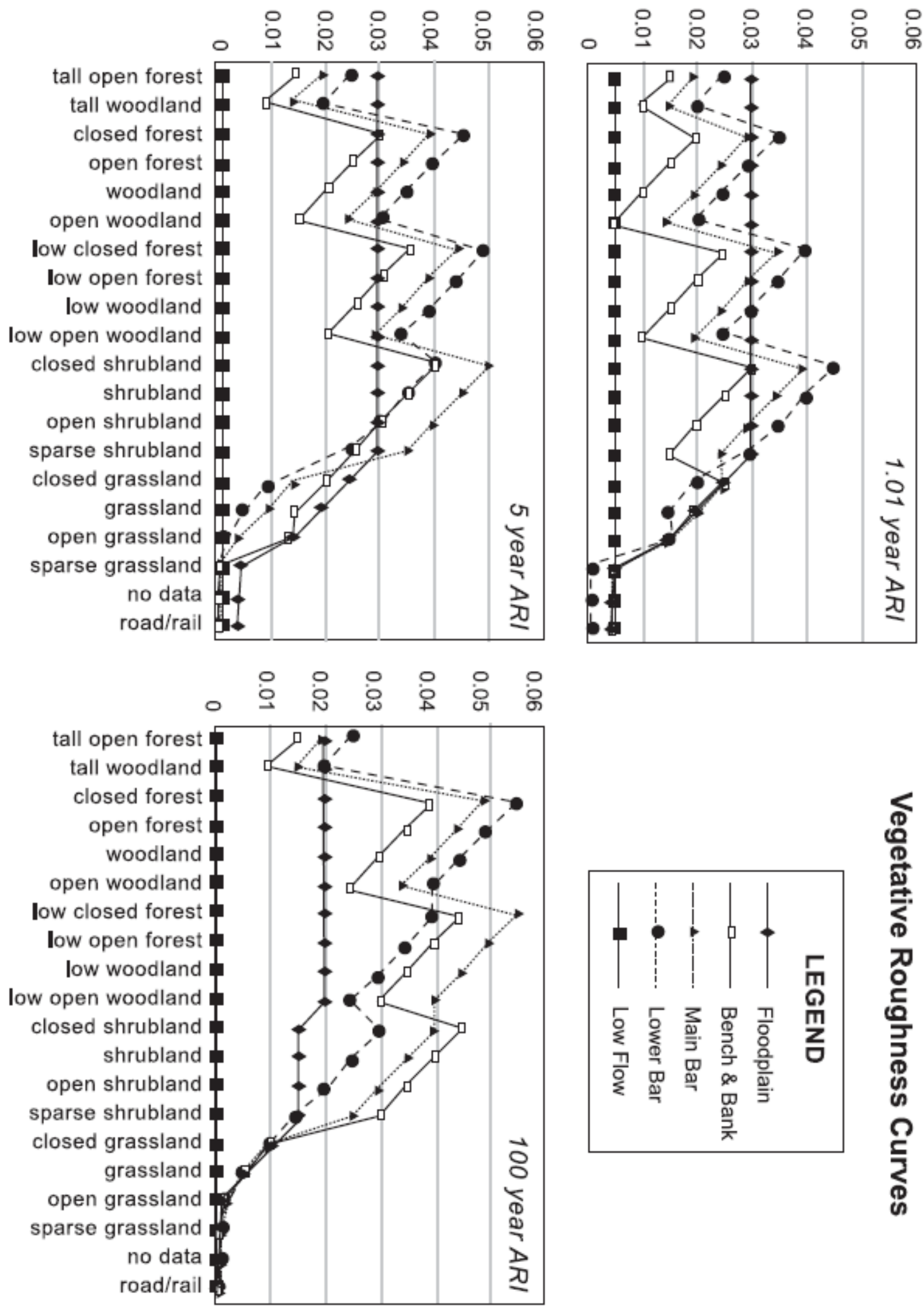




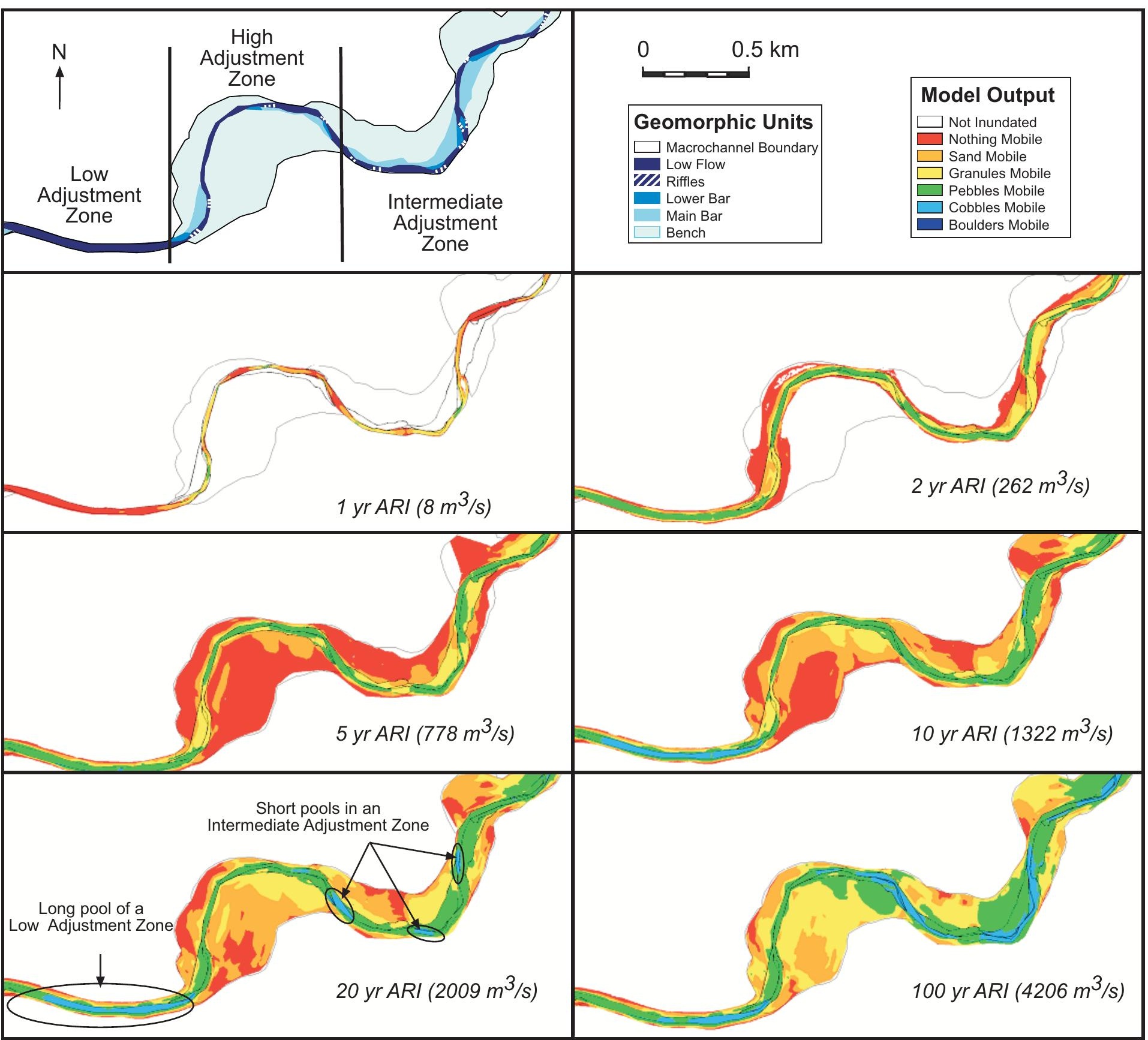




LEGEND Bench Main Bar Low Bar $\quad$ Low Flow

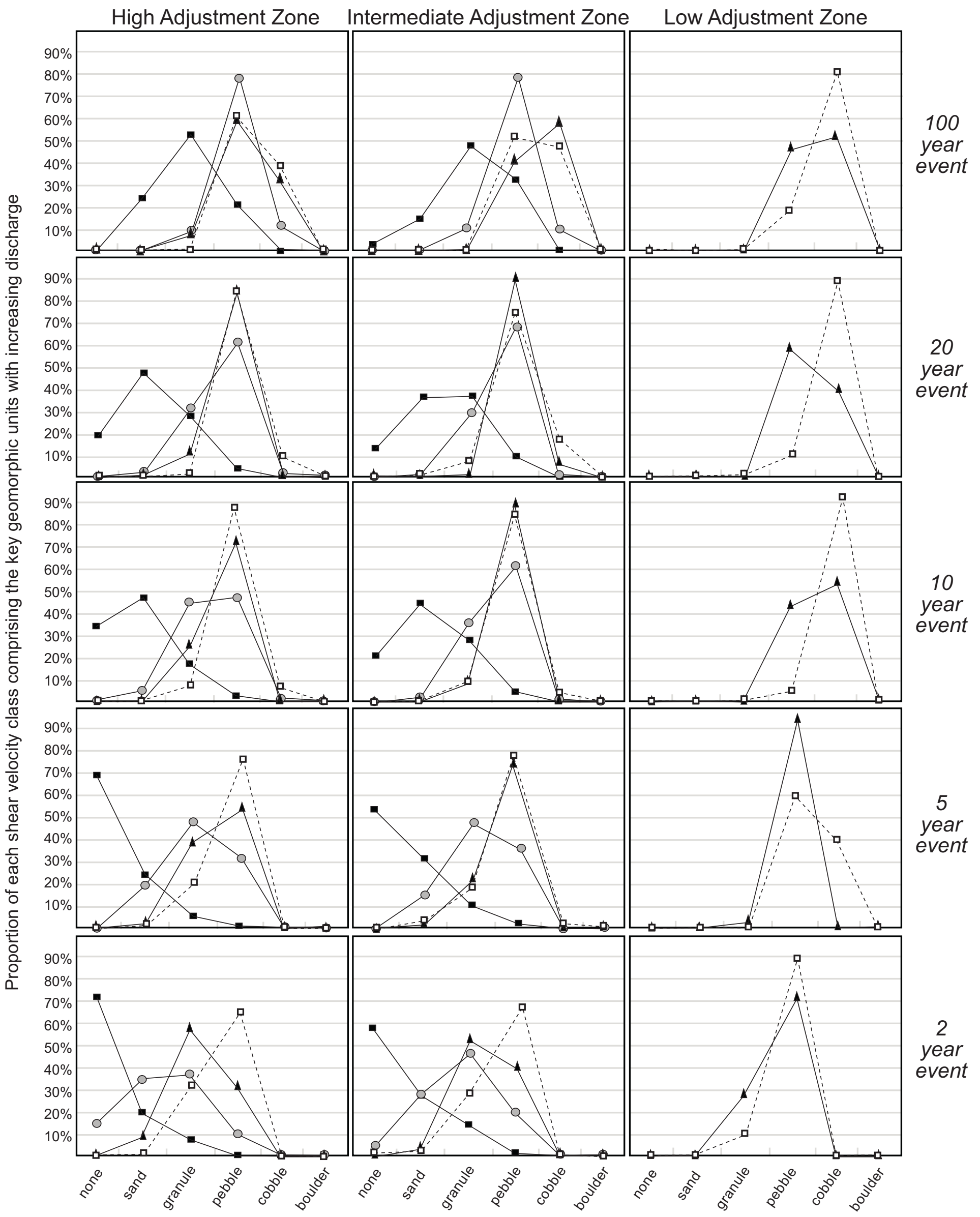

Shear velocity classes representing the size of potentially mobile sediment across the adjustment zones 


\section{A) REHABILITATION PRIORITY BASED ON MODELLED RISK OF BEDLOAD EROSION}

geomorphic units, inundation frequency and dominant substrate calibre indicated

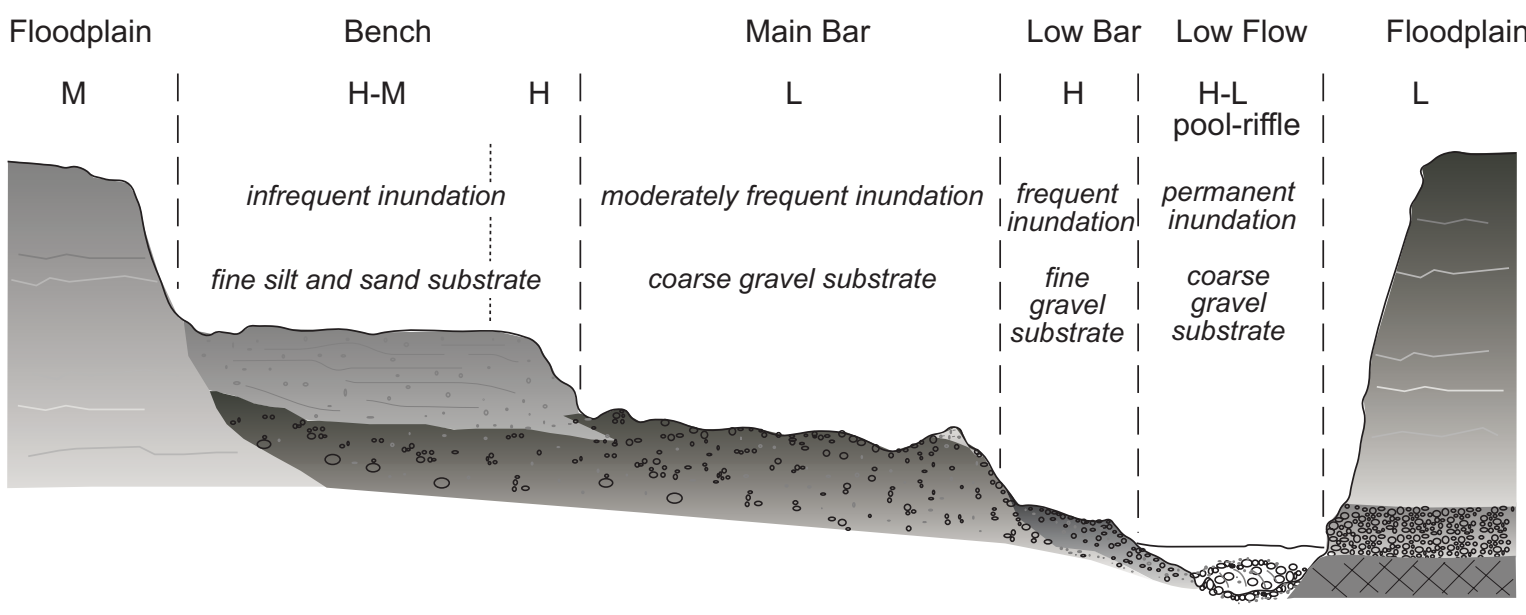

B) REHABILITATION PRIORITY BASED ON REVEGETATION SURVIVORSHIP RATES

groundwater access and soil moisture retention are indicated

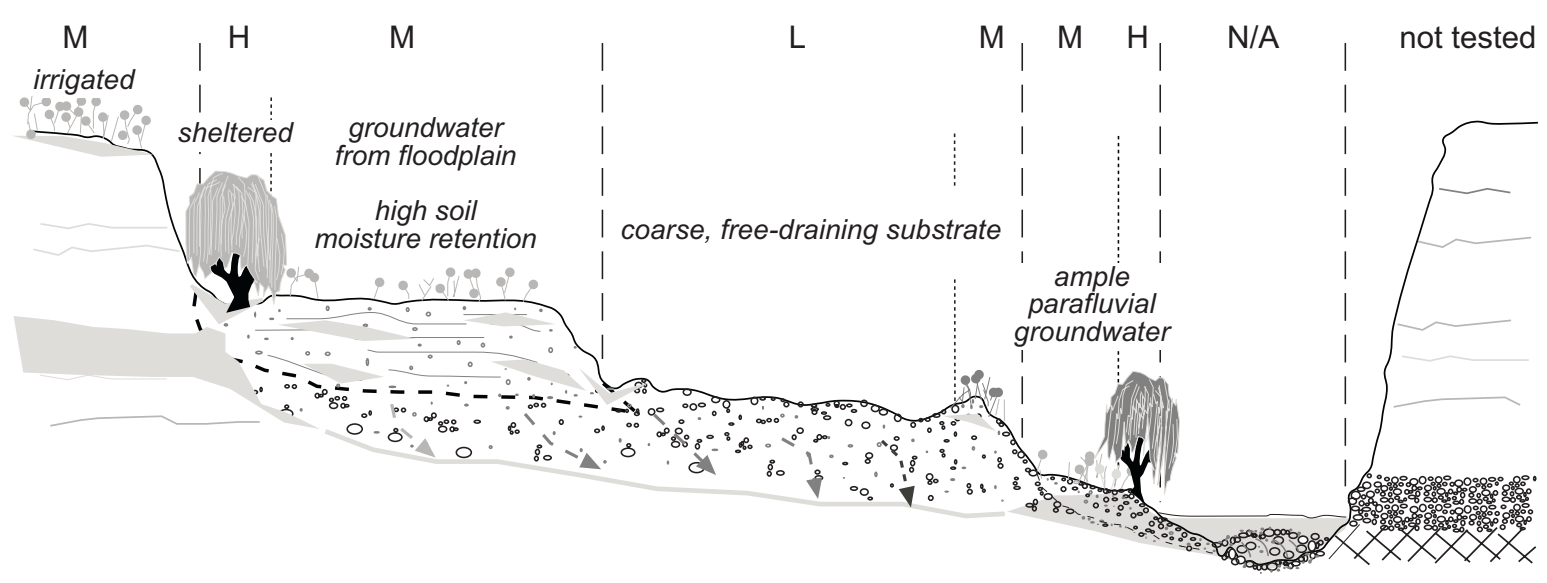

\section{C) OVERALL REHABILITATION PRIORITY}

Riparian buffe strip recommended at floodplain margin to reduce input of agricultural nutrients
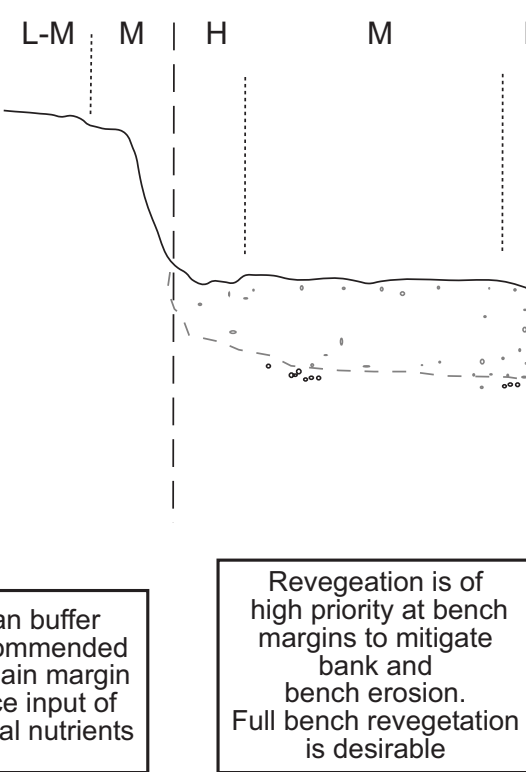

Low erosion risk and low revegetation success, revegetation not recommended, except perhaps on ridge at margin of low bar to encourage depsition on bar.

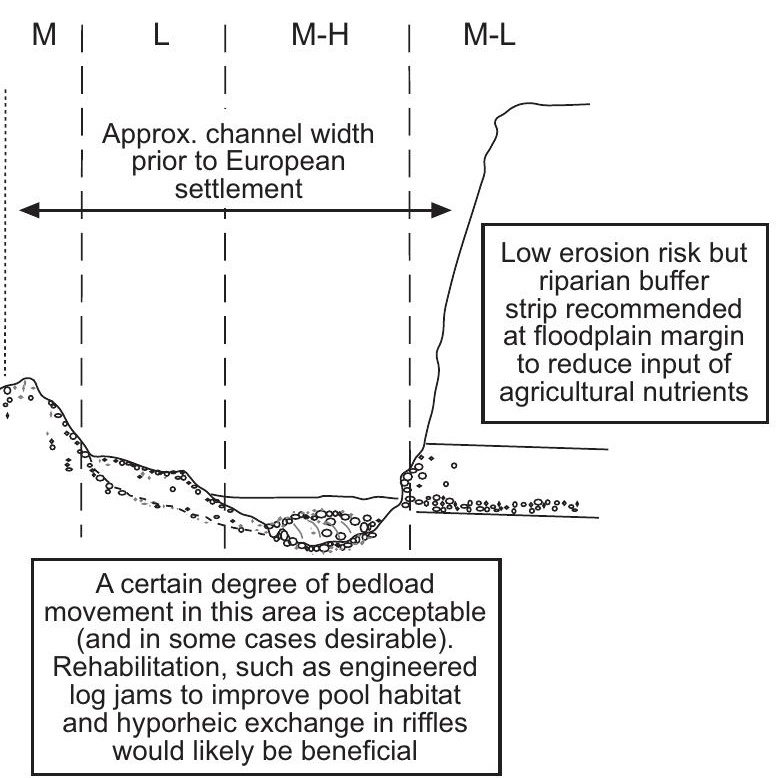




\section{Tables}

\section{Table 1}

\begin{tabular}{|c|c|c|c|c|}
\hline \multirow{2}{*}{$\begin{array}{c}\text { Form and } \\
\text { Height class }\end{array}$} & \multicolumn{4}{|c|}{ Projective Foliage Cover of Tallest Stratum } \\
\cline { 2 - 5 } & $70-100 \%$ & Mid density & Sparse & Very sparse \\
\hline $\begin{array}{c}\text { Trees }>30 \mathrm{~m} \\
\text { (very rare) }\end{array}$ & Tall closed forest & Tall open forest & Tall woodland & Tall open woodland \\
\hline Trees 10-30m & Closed forest & Open forest & Woodland & Open woodland \\
\hline Trees 5-10m & Low closed forest & Low open forest & Low woodland & Low open woodland \\
\hline Shrubs 1-5m & Closed shrubland & Shrubland & Open shrubland & Sparse shrubland \\
\hline Grasses 0-1m & Closed Grassland & Grassland & Open Grassland & Sparse Grassland \\
\hline
\end{tabular}

\section{Table 2}

\begin{tabular}{|c|c|c|c|c|c|c|c|}
\hline $\begin{array}{l}\text { Geomorphic } \\
\text { Unit }\end{array}$ & $\begin{array}{c}\mathbf{n}_{\text {Total }} \\
\mathbf{m}\left(\mathbf{n}_{\mathbf{b}}+\mathbf{n}_{1}+\mathbf{n}_{2}+\mathbf{n}_{3}+\mathbf{n}_{4}\right)\end{array}$ & $\begin{array}{c}\text { m } \\
\text { (channel } \\
\text { sinuosity) }\end{array}$ & $\begin{array}{c}\mathbf{n}_{\mathbf{b}} \\
\text { (base } \\
\text { material) }\end{array}$ & $\begin{array}{c}\mathbf{n}_{1} \\
\text { (channel } \\
\text { irregularity) }\end{array}$ & $\begin{array}{c}\mathbf{n}_{2} \\
\text { (xs } \\
\text { variation) }\end{array}$ & $\begin{array}{c}\mathbf{n}_{3} \\
\text { (obstructions) }\end{array}$ & $\begin{array}{c}\mathrm{n}_{4} \\
\text { (vegetation) }\end{array}$ \\
\hline Floodplain & $0.029-0.058$ & $\begin{array}{c}1 \\
\text { S negl. }\end{array}$ & $\begin{array}{c}0.025 \\
\text { Firm soil }\end{array}$ & $\begin{array}{l}0.0015 \\
\text { Minor }\end{array}$ & $\begin{array}{c}0 \\
\text { N/A }\end{array}$ & $\begin{array}{c}0.001 \\
\text { Negl. }<5 \%\end{array}$ & $\begin{array}{c}\text { 0.03-0.001 } \\
\text { spatially } \\
\text { variable }\end{array}$ \\
\hline $\begin{array}{c}\text { Bank \& } \\
\text { Bench }\end{array}$ & $0.032-0.082$ & $\begin{array}{c}1.15 \\
S<1.5\end{array}$ & $\begin{array}{c}0.026 \\
\text { Coarse } \\
\text { sand }\end{array}$ & $\begin{array}{l}0.002 \\
\text { Minor }\end{array}$ & $\begin{array}{c}0.002 \\
\text { occasional }\end{array}$ & $\begin{array}{c}0.001 \\
\text { Negl. }<5 \%\end{array}$ & $\begin{array}{c}0.045-0.001 \\
\text { spatially } \\
\text { variable }\end{array}$ \\
\hline Main Bar & $0.036-0.097$ & $\begin{array}{c}1.15 \\
S<1.5\end{array}$ & $\begin{array}{c}0.03 \\
\text { cobble }\end{array}$ & $\begin{array}{l}0.0015 \\
\text { Minor }\end{array}$ & $\begin{array}{c}0.002 \\
\text { occasional }\end{array}$ & $\begin{array}{c}0.001 \\
\text { Negl. }<5 \%\end{array}$ & $\begin{array}{c}\text { 0.055-0.001 } \\
\text { spatially } \\
\text { variable }\end{array}$ \\
\hline Lower Bar & $0.033-0.094$ & $\begin{array}{c}1.15 \\
S<1.5\end{array}$ & $\begin{array}{l}0.028 \\
\text { gravel }\end{array}$ & $\begin{array}{l}0.001 \\
\text { Minor }\end{array}$ & $\begin{array}{c}0.002 \\
\text { occasional }\end{array}$ & $\begin{array}{c}0.001 \\
\text { Negl. }<5 \%\end{array}$ & $\begin{array}{c}\text { 0.055-0.001 } \\
\text { spatially } \\
\text { variable }\end{array}$ \\
\hline Low Flow & $0.04-0.052$ & $\begin{array}{c}1.15 \\
S<1.5\end{array}$ & $\begin{array}{c}0.03 \\
\text { cobble }\end{array}$ & $\begin{array}{l}0.0005 \\
\text { V. minor }\end{array}$ & $\begin{array}{c}0.003 \\
\text { occasional }\end{array}$ & $\begin{array}{c}0.007 \\
\text { Minor }<15 \%\end{array}$ & $\begin{array}{c}0.005-0 \\
\text { small }\end{array}$ \\
\hline
\end{tabular}

Table 3

\begin{tabular}{|c|c|}
\hline Flood ARI (yr) & Discharge $\mathbf{( m}^{\mathbf{3}} \mathbf{s} \mathbf{)}$ \\
\hline 1 & 8 \\
2 & 260 \\
Calibration flood & 370 \\
3 & 470 \\
4 & 640 \\
5 & 780 \\
10 & 1,300 \\
20 & 2,000 \\
50 & 3,150 \\
100 & 4,200 \\
\hline
\end{tabular}


Table 4.

\begin{tabular}{|c|c|c|c|c|c|c|c|}
\hline \multirow{3}{*}{ SUMMARY } & Groups & Count & Sum & Average & Variance & & \\
\hline & Measured Flood Heights & 85 & 11154 & 131.23 & 5.29 & & \\
\hline & Modelled Flood Heights & 85 & 11137 & 131.02 & 5.55 & & \\
\hline \multirow{4}{*}{ ANOVA } & Source of Variation & SS & $d f$ & MS & $\boldsymbol{F}$ & P-value & F crit \\
\hline & Between Groups & 1.76 & 1 & 1.76 & 0.32 & 0.57 & 3.90 \\
\hline & Within Groups & 909.80 & 168 & 5.42 & & & \\
\hline & Total & 911.56 & 169 & & & & \\
\hline
\end{tabular}

Table 5.

\begin{tabular}{|c|c|c|c|c|c|c|c|c|c|}
\hline & & D84 & D50 & $\%$ sand & $\mathbf{T}^{*} \mathbf{c i}(0)$ & $\mathrm{T}^{*} \operatorname{ci}(1)$ & $\begin{array}{l}\mathbf{T}^{*} \mathbf{c i} \\
\text { (bimodal) }\end{array}$ & $\begin{array}{l}\text { Tci } \\
\text { (dimensionful) }\end{array}$ & $\begin{array}{l}\mathbf{u}^{*} \mathbf{c} \\
\text { (critical } \\
\text { shear } \\
\text { velocity) }\end{array}$ \\
\hline \multirow{5}{*}{\multicolumn{2}{|c|}{$\begin{array}{l}\text { sand } \\
\text { granule } \\
\text { pebble } \\
\text { cobble } \\
\text { boulder } \\
\end{array}$}} & 2 & 1.0 & $100 \%$ & 0.022 & 0.033 & 0.033 & 1.07 & 0.033 \\
\hline & & 4 & 2.5 & $30 \%$ & 0.027 & 0.041 & 0.041 & 2.66 & 0.052 \\
\hline & & 38 & 10.0 & $0 \%$ & 0.011 & 0.017 & 0.011 & 6.96 & 0.083 \\
\hline & & 256 & 45.0 & $0 \%$ & 0.008 & 0.012 & 0.008 & 31.32 & 0.177 \\
\hline & & 400 & 300.0 & $0 \%$ & 0.032 & 0.050 & 0.032 & 208.81 & 0.457 \\
\hline \multirow[t]{7}{*}{ Facies } & $1 a$ & 2 & 1.0 & $84 \%$ & $\mathrm{n} / \mathrm{a}$ & 0.033 & $\mathrm{n} / \mathrm{a}$ & 1.07 & 0.033 \\
\hline & $1 b$ & 51 & 7.8 & $18 \%$ & 0.007 & 0.010 & 0.010 & 8.05 & 0.090 \\
\hline & $2 a$ & 121 & 58.5 & $8 \%$ & 0.021 & 0.032 & 0.028 & 55.39 & 0.235 \\
\hline & $2 b$ & 27 & 7.5 & $21 \%$ & 0.012 & 0.018 & 0.018 & 7.86 & 0.089 \\
\hline & $3 a$ & 55 & 23.6 & $12 \%$ & 0.018 & 0.028 & 0.026 & 23.54 & 0.153 \\
\hline & $3 \mathbf{b}$ & 44 & 25.0 & $3 \%$ & 0.024 & 0.038 & 0.029 & 20.59 & 0.144 \\
\hline & 3c & 72 & 41.3 & $3 \%$ & 0.025 & $\mathrm{n} / \mathrm{a}$ & $\mathrm{n} / \mathrm{a}$ & 28.71 & 0.169 \\
\hline
\end{tabular}

